Review Article

\title{
Cytochrome P450 and P-Glycoprotein-Mediated Interactions Involving African Herbs Indicated for Common Noncommunicable Diseases
}

\author{
Gregory Ondieki, ${ }^{1}$ Makafui Nyagblordzro, ${ }^{1}$ Siambi Kikete, ${ }^{1}$ \\ Rongjia Liang, ${ }^{1}$ Lili Wang, ${ }^{1,2}$ and Xin $\mathrm{He}^{1,2}$ \\ ${ }^{1}$ School of Chinese Materia Medica, Tianjin University of Traditional Chinese Medicine, Nankai District, Tianjin 300193, China \\ ${ }^{2}$ Tianjin State Key Laboratory of Modern Chinese Medicine, Tianjin 300193, China \\ Correspondence should be addressed to Xin He; hexintn@163.com
}

Received 7 November 2016; Revised 26 December 2016; Accepted 4 January 2017; Published 31 January 2017

Academic Editor: Olumayokun A. Olajide

Copyright (C) 2017 Gregory Ondieki et al. This is an open access article distributed under the Creative Commons Attribution License, which permits unrestricted use, distribution, and reproduction in any medium, provided the original work is properly cited.

\begin{abstract}
Herbal remedies are regularly used to complement conventional therapies in the treatment of various illnesses in Africa. This may be because they are relatively cheap and easily accessible and are believed by many to be safe, cause fewer side effects, and are less likely to cause dependency. On the contrary, many herbs have been shown to alter the pharmacokinetics of coadministered allopathic medicines and can either synergize or antagonize therapeutic effects as well as altering the toxicity profiles of these drugs. Current disease burden data point towards epidemiological transitions characterised by increasing urbanization and changing lifestyles, risk factors for chronic diseases like hypertension, diabetes, and cancer which often present as multimorbidities. As a result, we highlight African herb-drug interactions (HDIs) modulated via cytochrome P450 enzyme family (CYP) and P-glycoprotein (P-gp) and the consequences thereof in relation to antihypertensive, antidiabetic, and anticancer drugs. CYPs are enzymes which account for to up to $70 \%$ of drug metabolism while P-gp is an efflux pump that extrudes drug substrates out of cells. Consequently, regulation of the relative activity of both CYP and P-gp by African herbs influences the effective drug concentration at the site of action and modifies therapeutic outcomes.
\end{abstract}

\section{Introduction}

Use of traditional herbal products as an alternative and/or to complement conventional therapies (or simply CAM) continues to be an area of interest [1]. Worldwide, a considerable proportion of the population relies, at least partly, on herbs for primary healthcare especially in the developing world $[2,3]$. Estimates of CAM use in some parts of Africa are at around $80 \%$ [4]. This noticeably high CAM utilization is fueled by a number of factors such as the ease of access, relative affordability, anecdotal perception of higher safety and efficacy, and natural abundance of these products as $25 \%$ of the world's higher plants, 5400 of which have medicinal value being found on the continent $[5,6]$.

Herbs are not used in isolation and concomitant use with conventional medicines is estimated at $20-30 \%$ in the United
States [7]. Increase in the incidence of noncommunicable diseases (NCDs) in Africa has, invariably, led to a tandem surge in concurrent herb use. In a survey in Nigeria, up to $46 \%$ of diabetes mellitus patients [8], 39.1\% of hypertensive patients [9], and $65 \%$ of cancer patients used or were using herbs alongside conventional drugs [10]. This poses unique challenges because (a) most herbs lack patient information, (b) available research about herbs is scanty, (c) there is poor regulation of CAM practice, and (d) there is a general lack of disclosure of herb users to their physicians [11-13].

Phytochemically, herbs are a repository of complex mixtures of bioactive compounds [14] that can potentially alter the pharmacokinetics of coadministered prescription drugs and/or herbs, especially absorption and oxidative metabolism $[1,15]$. This is possible through inhibition or induction of intestinal and hepatic drug metabolizing enzymes like CYP, 
as well as efflux and transport proteins which have been touted as the main mechanism for HDI $[11,16]$. HDI occurs when a herbal preparation interferes with the metabolism of a coadministered conventional drug(s) by interacting with the enzyme for which it is a substrate hence causing an apparent alteration in the plasma concentration of the affected drug hence affecting its normal pharmacokinetic profile [17, 18]. The interaction is of more importance especially for drugs with narrow therapeutic window as the consequences are lifethreatening [19].

By herbs modulating CYP activity, pronounced pharmacokinetic changes in a concomitantly given drug may be observed [20].

African herbs are not covered in the text but are commonly used in management of NCDs; some of their important phytochemical composition and pharmacokinetic effects on CYP and/or P-gp have been summarized in Table 1. Similarly, some selected compounds known to affect the activities of CYP and P-gp are shown in Figure 2. Invariably, use of herbs as remedy for various diseases and conditions will most likely depend on geographical location and folklore use among the populace. Therefore, in this review the classification of herbs as discussed here is based on their most common use.

\section{Prevalence and Comorbidity of Diabetes, Hypertension, and Cancer in Africa}

Dynamics of disease patterns have changed in favour of noncommunicable diseases (NCDs) on the continent [21, 22]. To a lesser extent, prevalence of NCDs appears to be influenced by genetics [23]. For instance, populations of African ancestry have a disproportionately higher burden of cancer and hypertension $[24,25]$.

At the beginning of the millennium, $37 \%$ of deaths in South Africa were attributed to NCDs with diabetes mellitus (DM), cancer, and cardiovascular diseases taking the lead [26]. In 2011, 30\% of the 9.5 million deaths in Africa and $25.8 \%$ of the 675.4 million disability-adjusted life years recorded in Sub-Saharan Africa were NCD linked [27, 28].

About $7.7 \%$ of the world population will be diabetic by 2030 with the incidence rates in developing countries increasing by $69 \%$ as compared to $20 \%$ for their developed counterparts mainly due to increase in risk factor exposure [29]. Among NCDs, hypertension is the leading cause of debilitations and disabilities in Africa prompting the African Union to declare it the greatest health challenge after HIV/AIDS [30, 31]. With this current trend, by 2025 there will be 126 million hypertension and a predicted 49.7 million DM patients on the continent by 2030 [32]. The crude prevalence of cancer in Africa is estimated at $0.3 \%$ [33] and those reported to be highly prevalent in Africa include ovarian, hepatobacillar, Kaposi's sarcoma, breast, and prostate cancers [34].

NCDs show comorbid tendencies. A survey in the US showed that up to $68.7 \%$ of cancer patients had other chronic condition(s) including DM and hypertension [35]. A cohort study by Gerber et al. revealed that there was $71 \%$ comorbidity rate for hypertension, cancer, and diabetes in elderly South Africans [36]. In another survey among primary healthcare

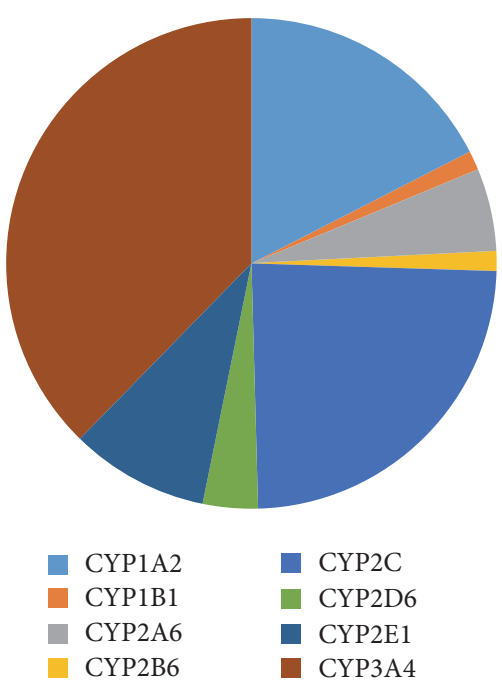

FIGURE 1: Relative abundances of important hepatic CYPs, adopted from Rendic and Di Carlo [40].

attendants in Western Cape, South Africa, 23\% of hypertension patients had DM and $40 \%$ of DM patients had hypertension [37].

\section{Role of CYP450 and P-Glycoprotein in Drug Metabolism}

3.1. CYP450. CYP450 refers to a large family of ironcontaining enzymes involved in phase I metabolism of exogenous or endogenous chemical entities where they act by introducing and/or exposing a polar moiety via oxidation, hydrolysis, or reduction [38]. Their classification is based on families. Those belonging to families 1,2 , and 3 are the principal xenobiotic metabolizers (Figure 1). The others are involved in biotransformation and elimination of various endogenous biomolecules such as fatty acids and hormones [39].

These oxidative enzymes account for up to $80 \%$ of phase I metabolism of therapeutic drugs in use [41]. CYP3A is the most dominant CYP and is the culprit in most drugdrug interactions [42]. Although present in many organs, the vast majority of the oxidative CYP450 enzyme systems are domiciled in the liver [43], with other organs, for instance, the small intestine being mostly dominated by CYP3A, in particular, CYP3A4 and CYP3A5 [44]. The review will focus on all the important CYPs and consequences of their inhibition or induction.

3.2. P-Glycoprotein. P-Glycoprotein is a transmembrane ATP-dependent efflux family of proteins that acts as a pump for a wide variety of chemically diverse substrates [45]. It is strategically located in various human tissues including the apical surface of intestinal epithelial cells, apical membrane of enterocytes, and renal tubules. In addition, it is expressed in tumour cells [46-48]. The human small intestines express Pgp or human multidrug resistance gene (MDR 1), multidrug resistance-associated protein 2 (MRP2), and breast cancer resistance protein (BCRP) which play a critical role in 


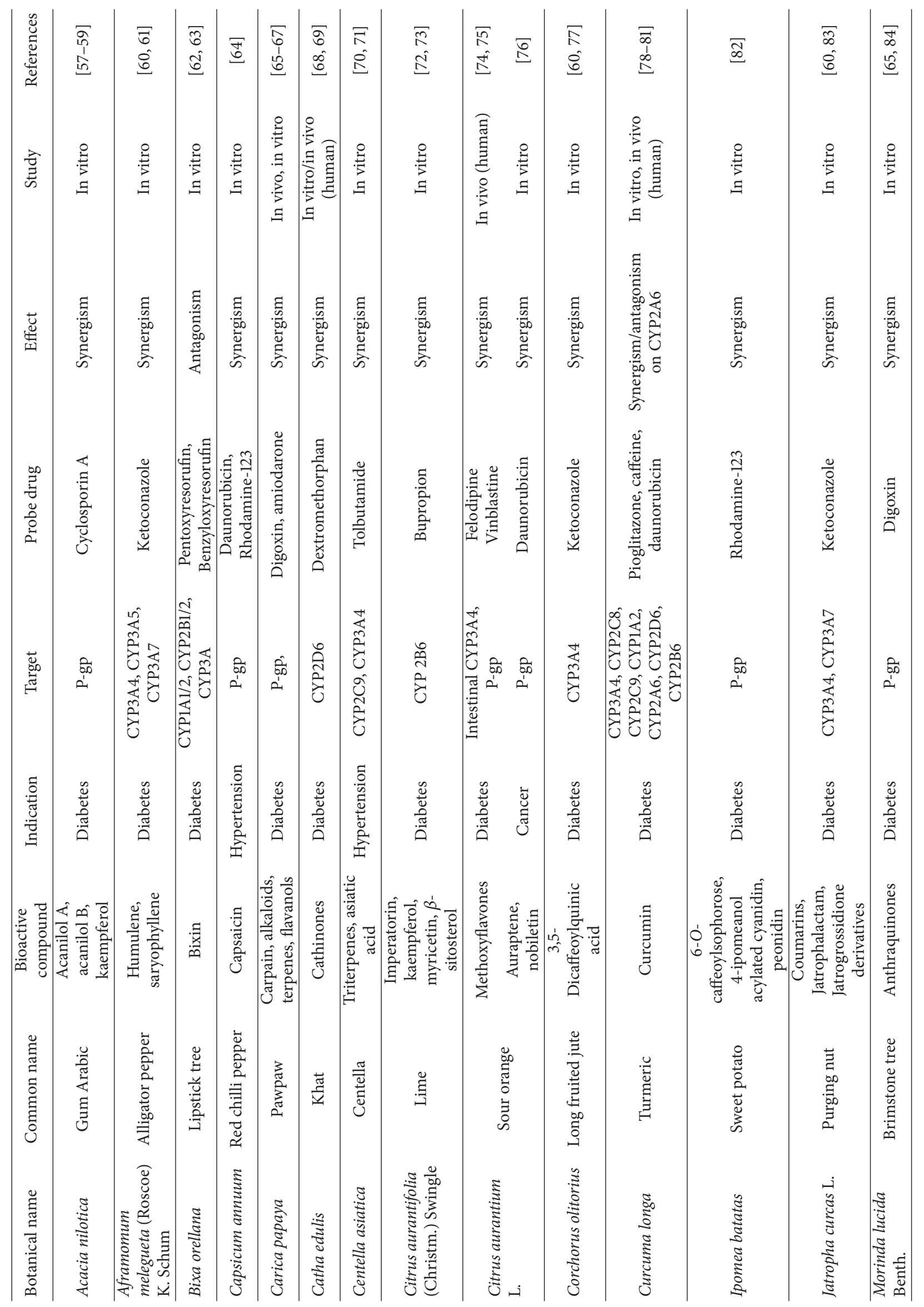




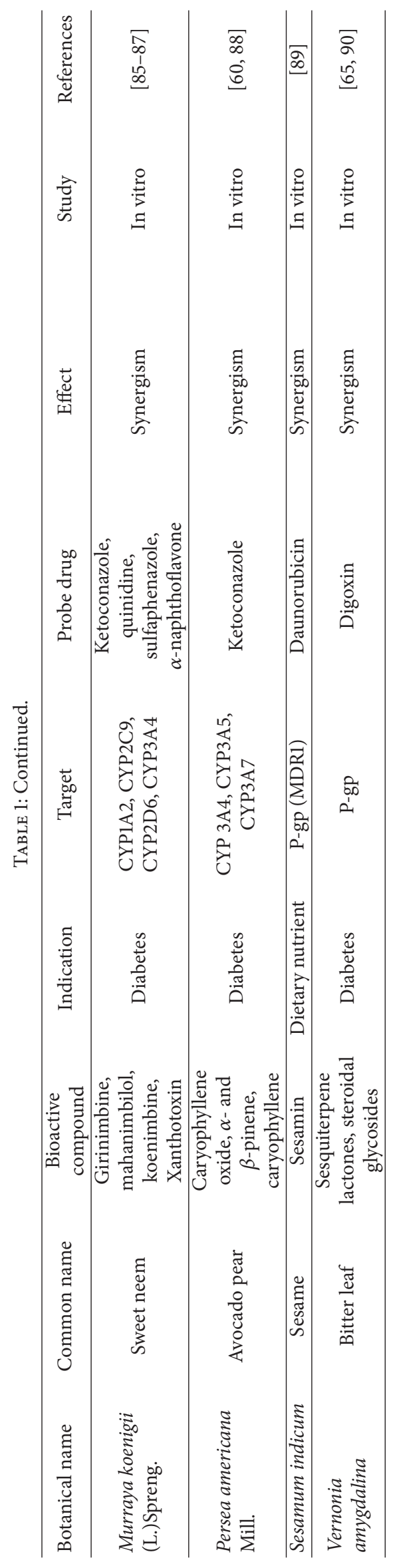




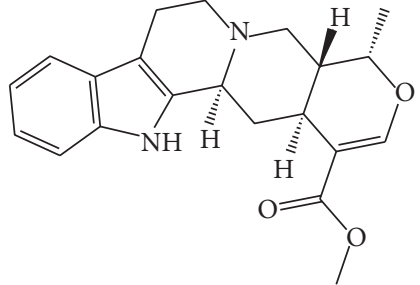

Ajmalicine<smiles>O=C1c2c(O)cc(O)c(O)c2OC(c2cc(O)c(O)c(O)c2)C1O[C@H]1C[C@H](CO)[C@@H](O)C(O)C1O</smiles>

Hibiscetin 3-glucoside<smiles>OC[C@H]1C[C@H](Oc2cc3c(O)cc(O)cc3[o+]c2-c2cc(O)c(O)c(O)c2)[C@H](O[C@@H]2OC[C@@H](O)[C@H](O)[C@H]2O)[C@H](O)[C@H]1O</smiles>

Delphinidin-3-O-sambubioside

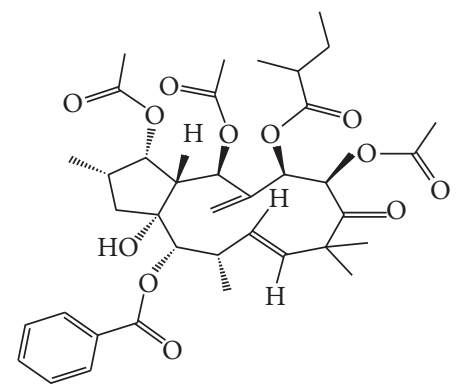

Tuckeyanol A<smiles>COC(=O)C(Cc1ccc2c(c1)OCO2)C(Cc1ccc2c(c1)OCO2)C(=O)OC</smiles>

Heliobuphthalmin

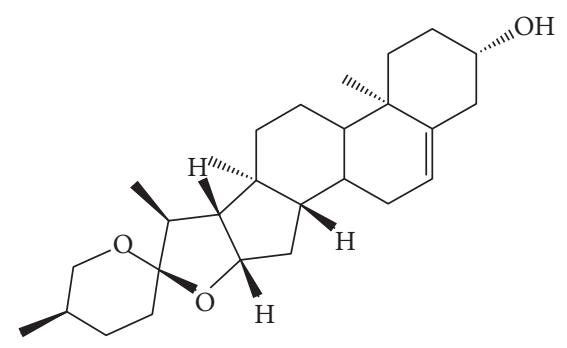

Diosgenin<smiles>OC[C@H]1O[C@@H](Oc2cc3c(O)cc(O)cc3[o+]c2-c2ccc(O)c(O)c2)[C@H](O[C@@H]2OC[C@@H](O)[C@H](O)[C@H]2O)[C@H](O)[C@H]1O</smiles>

Cyanidin-3-O-sambubioside<smiles>CN1CCc2cc3c(c4c2[C@@H]1Cc1ccccc1-4)OCO3</smiles>

(-)-Roemerine

Mangiferin<smiles>COC[C@H](Cc1ccc(OC)c(OC)c1)[C@H](COC)Cc1ccc(OC)c(OC)c1</smiles>

Phyllanthin

FIgure 2: Continued. 
<smiles>COC(=O)/C=C/C(C)=C/C=C/C(C)=C/C=C/C=C(C)/C=C/C=C(C)/C=C/C(=O)O</smiles>

Bixin<smiles>COC[C@H]1Cc2cc(OC)c3c(c2[C@@H](c2ccc(OC)c(OC)c2)[C@H]1COC)OCO3</smiles>

Hypophyllanthin<smiles>CC(=CCOc1c2ccoc2cc2oc(=O)ccc12)CCC(O)C(C)(C)O</smiles>

6, 7-Dihydrobergamottin

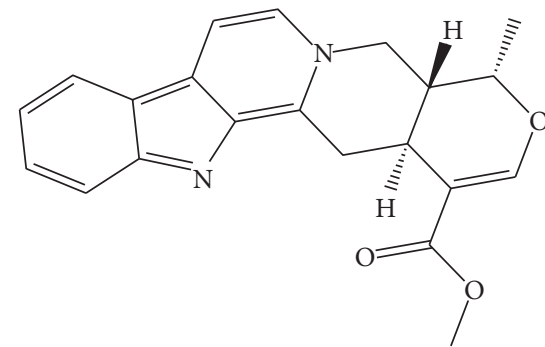

Serpentine

FIgURE 2: Selected phytochemicals extracted from African herbs that modulate CYP or P-gp.

drug pharmacokinetics such as absorption, distribution, and elimination by their efflux action $[49,50]$. MDR1 expressed by tumour cells affects chemotherapeutic drug concentration in these cells and in the process confers resistance to them [51]. It has been well demonstrated that P-gp is a victim of inhibition, induction, or activation by drugs just like CYP; thus it is a major cause of clinical drug-drug/herb interactions if and when they are concurrently administered $[45,52]$. Inhibition of P-gp leads to enhanced bioavailability of its substrate molecules [53]. The converse is true where there is induction.

Induction of P-gp or drug metabolizing enzyme can lead to therapeutic failure and goes unnoticed especially in cancer treatment [16]. This phenomenon can, alternatively, be exploited to positively alter the pharmacological properties of some drugs [54]. P-gp expression and activity have been known to increase with age [55] and certain infectious diseases [56] and in prolonged cancer chemotherapy [51].

The effect on drug pharmacokinetics with regard to herbs encompasses all aspects of absorption, distribution, metabolism, and excretion [91] as well as genetic regulation of certain metabolic proteins [92]. Most of these aspects have been aptly covered by other authors and we will limit our scope to interactions involving P-gp and CYPs as pertains to African herbs.

\section{African Herbs Used for Common NCDs Modulating CYP450 or P-gp Function and Their Interactions}

4.1. Diabetes Mellitus. Diabetic condition is physiologically heralded by sustained hyperglycaemia [93] and if it is undetected and/or effectively managed, its long term complications including organ failure, blood vessels, and nerve damage are debilitating [94]. The pharmacological mainstay in diabetes management is by the use of oral antidiabetic drugs (OADs) broadly classified as biguanides, glitinides, sulfonylureas, or thiazolidinediones as well as insulin for effective hypoglycemic control [95]. It has been observed that patients on identical OAD regimens exhibit notable variations in glycaemic control, efficacy, tolerability, and adverse effects, a phenomenon attributed to differences in genes leading to varying expression of CYP and drug transporters involved in various aspects of drug metabolism and disposition of these drugs [96]. Similarly, owing to their complex phytochemical composition, when herbs are concomitantly administered with OADs or any other conventional drug(s) indicated for NCDs, modification of pharmacological effects of these drugs cannot be ruled out. It is important therefore that specific effects on metabolic enzymes and drug transporters of these useful herbs and the components isolated from them are known and documented to ensure their safe medical utilization.

4.1.1. Trigonella foenum-graecum (Fenugreek). Trigonella foenum-graecum is a herb in Leguminosae family that grows in Mediterranean areas of Africa and is used in management of diabetes and hyperlipidaemia [97, 98]. Phytochemically, Trigonella foenum-graecum ( $T$. foenum) contains, among other compounds, tannic acid, volatile oils, fixed oils, fiber, steroidal saponins, vitamins A, B1, B2, B3, and C, flavonoids, coumarins, and amino acids [99-101]. 
CYP2D $m$ RNA expression was depressed in rats put on a seven-day regimen of $T$. foenum as determined by a reduction in dextromethorphan metabolism [102]. In a related in vitro experiment using human liver microsomes, $T$. foenum extract at concentrations of $50-100 \mu \mathrm{g} / \mathrm{mL}$ inhibited both CYP3A4 and CYP2D6 [103]. Another investigation using tolbutamide as a substrate showed a dose-related inhibition of gene expression coupled with a reduction in metabolic activity of CYP2C11 [104]. Concomitant administration of antidiabetic drug glibenclamide with $T$. foenum significantly increased the plasma concentration of the former in beagle dogs via an interaction whose mechanism is unknown [105]. However, diosgenin-a steroidal saponin contained in fenugreek has been shown to significantly inhibit CYP3A4 [106]. This may be one of the compounds involved and further research may reveal others involved in CYP modulation.

4.1.2. Kalanchoe crenata (Dog's Liver). Kalanchoe crenata is a herbaceous plant of the Crassulaceae family native to Madagascar and widespread in tropical Africa [107]. It is popular in parts of Cameroon where it is traditionally used to treat diabetes. Phytoconstituents of K. crenata include tannins, terpenoids, saponins, polysaccharides, alkaloids, and flavonoids.

An in vivo study showed that water-alcohol extract of the plant caused hypoglycaemia and an increased glucose sensitivity analogous to glibenclamide [108]. In a recent in vitro study, a methanol extract and various fractions of the herb were incubated with human hepatic microsomes or recombinant human CYP3A4 and CYP2C19 in a cocktail experiment. The extract and three fractions showed a considerable inhibition of CYP3A4 in a time-dependent manner with the extract being the most potent. Also, the crude extract and one fraction exhibited a time-dependent inhibition of CYP3A4 [109].

4.1.3. Nigella sativa (Black Seed). Nigella sativa is a herbaceous plant belonging to Ranunculaceae family. $N$. sativa is native to countries in the Mediterranean region where it is used as a spice and for treatment various conditions including diabetes and hypertension [110]. Several important compounds have been identified in the volatile oil of $N$. sativa seeds including thymoquinone, thymohydroquinone, thymol, carvacrol, nigellidine, and $\alpha$-pinene [111]. In an in vivo study in rabbits, $N$. sativa volatile oil extract given intraperitoneally at $50 \mathrm{mg} / \mathrm{kg}$ caused a considerable reduction in blood sugar [112]. A study demonstrated that $N$. sativa seeds extract dramatically inhibits the intestinal electrogenic absorption of glucose in vitro [113]. It has been demonstrated that $N$. sativa seeds extract possesses hepatic CYP3A4 and CYP2D6 inhibition both in vitro and in vivo [114] and this may be of pharmacokinetic impact on OADs which are substrates of these enzymes.

In an in vivo study, administration of $N$. sativa for a week resulted in significant reduction of gene expression as well as metabolic activity of CYP2D [102]. A similar experiment using tolbutamide as a substrate showed that its oil extract had considerable inhibitory effects on CYP2C11 [104]. However, when $N$. sativa was coadministered with cyclosporine in an animal model, the oral bioavailability of cyclosporine was significantly reduced suggestive of the possibility that
$N$. sativa causes induction of intestinal P-gp and/or CYP3A4 [115]. The ability of this herb to either induce or inhibit CYP3A4 and the potential for HDIs thereof, especially with regard to OADs, may need to be studied further.

4.1.4. Phyllanthus amarus (Gulf Leaf Flower). Phyllanthus amarus is a herb in Euphorbiaceae family. It is broadly considered as a hepatoprotective and hypoglycaemic agent by traditional practitioners as well as conventional researchers $[116,117]$. It is rich in bioactive compounds including lignans, terpenoids, alkaloids, coumarins, tannins, polyphenols, and flavonoids [118]. An in vitro study showed that ethanolic extract of $P$. amarus significantly inhibited CYP3A5 and CYP3A7 [60]. P. amarus whole plant, as well as its roots, stem, and leaf extracts, showed considerable inhibition of CYP1A2 and CYP2C9 across a range of concentrations [119]. In another study, water and ethanol extracts of $P$. amarus demonstrated a significant dose-related inhibition of human hepatic CYP1A2, CYP2D6, CYP2E1, and CYP3A4. This effect was superior to that caused by ketoconazole. Two lignans derived from $P$. amarus, hypophyllanthin and phyllanthin, showed a mechanism based inhibition (MBI) of CYP3A4 [120]. In MBI, the reactive oxidative metabolites bind covalently to CYP enzymes hence deactivating them in a more permanent manner as opposed to reversible inhibition. The inhibition effect of $P$. amarus on CYP3A4, therefore, may be more physiologically prolonged. In an in vivo study, there was a significant increase of the AUC, $C_{\max }, T_{\max }$, and $T_{1 / 2}$ of midazolam when rabbits were pretreated with $500 \mathrm{mg} / \mathrm{kg}$ of $P$. amarus extract for 7 days prior to administration of midazolam, a CYP3A substrate [121]. In a related study in rats, a single dose of $P$. amarus showed significant inhibition of intestinal CYP3A. Interestingly, repeated dosing had a modest induction effect on hepatic CYP2B and CYP3A. This dual effect shows potential interaction with drugs known to be inducers or inhibitors of the affected enzymes [122].

4.1.5. Lepidium sativum L. (Pepper Grass). Lepidium sativum is a herb belonging to Brassicaceae family and is native to Morocco where traditionally its seeds are used to manage diabetes [123]. The seeds are used in diabetes management and contain free fatty acids, amino acids, tocopherols, and several phenolic compounds including quercetin [124]. In one study, $10 \mathrm{mg} / \mathrm{kg} / \mathrm{h}$ of L. sativum water extract given intravenously in normal and diabetes-induced rats led to a decrease in blood glucose with a concomitant increase in urinary glucose in both groups. The extract may be exerting its hypoglycaemic effect renally by decreasing glucose reuptake [125]. In an in vitro study, ethanolic extract and seed powder of L. sativum when incubated with human liver microsomes showed significant inhibition of CYP2D6 and CYP3A4. The in vitro outcome was confirmed in vivo as the inhibition was corroborated in healthy human subjects. This implies the presence of a higher degree of clinical HDI interactions [126]. Its effect on CYP2D at the gene level has also been investigated and analysis of rat hepatic CYP2D $m$ RNA expression after a 7-day regimen on $L$. sativum extract showed that the herb reduced the production of CYP2D and caution may be necessary when substrates of the affected CYP are used with the herb [102]. 
When coadministered with cyclosporine in an animal model, L. sativum had a statistically insignificant increase in AUC and clearance of cyclosporine. However, the elimination rate of cyclosporine was significantly decreased due to inhibition of CYP3A and modulation of intestinal P-gp [115]. Its effect on CYP2D at the gene level has also been investigated and analysis of rat hepatic CYP2D $m$ RNA expression after a 7-day regimen on $L$. sativum extract showed that the herb caused a significant reduction in the production of CYP2D [102]. Therefore, its effects on CYP2D substrates can be present even where there is no concomitant administration.

4.2. Hypertension. The main goal of therapy in the treatment of hypertension is to lower systemic blood pressure down to an optimum range via the use of antihypertensive medications and other nonpharmacologic therapies. Owing to that, the frequently used classes of antihypertensive drugs, in particular, beta-blockers, calcium channel blockers (CCB), angiotensin converting enzyme (ACE) inhibitors, and diuretics, incidentally, are used in combination with herbal medications $[127,128]$. In addition, some antihypertensive drugs are not devoid of CYP450 enzyme metabolism and P-gp interactions, and hence coincidental herd-drug interactions emanating from CYP450 substrates and the seemingly innocuous herbal medicines used in managing hypertension might trigger unknown reactions.

Artemisia herba-alba and Hibiscus sabdariffa, so far, have been researched at the level of CYP450 microsomal enzymes and its blood pressure lowering capabilities, but interactions relating to P-gp still remain elusive.

4.2.1. Artemisia herba-alba (White Wormwood). A. herbaalba, native to Northern Africa $[129,130]$ and in Errachidia province of Morocco, is a major herbal drug used in the management of essential hypertension [131].

Zeggwagh et al. demonstrated that the aqueous extract of white wormwood extensively ameliorated spontaneous hypertension in rats [132] leading to the identification of sesquiterpene lactones as among the most pharmacologically active compounds [133, 134]. Other bioactive phytochemicals include herbalbin, cis-chrysanthenyl acetate, flavonoids (hispidulin and cirsilineol), and monoterpenes [135, 136].

The essential oils of $A$. herba-alba were found to inhibit angiotensin converting enzyme (ACE) [137] while the sesquiterpenes showed CYP3A4 and CYP2D6 inhibitory activities when tested against erythromycin and dextromethorphan $[138,139]$. The flavonoid $\alpha$-thujone is principally metabolized in the human liver mainly by CYP2A6 followed by CYP3A4 and to a lesser extent CYP2B6. Nevertheless, its inhibitory and inductive capabilities remain unstudied [140].

4.2.2. Hibiscus sabdariffa (Hibiscus/Roselle). Hibiscus is native to West Africa and is believed to have originated from Sudan. Folkloric uses include food, beverage (tea), and medicine where it is believed to have antihypertensive properties with flavonoids (delphinidin-3-O-sambubioside and related compounds) being responsible for these effects [141].

Clinically, $H$. sabdariffa's potency in controlling moderate essential hypertension [142] was comparable to captopril
[143]. It was also reported to increase urine outlet and mean AUC when coadministered with hydrochlorothiazide [144].

Ethanolic extracts were found to inhibit CYP1A2, CYP2A6, CYP2B6, CYP2C8, CYP2C9, CYP2C19, CYP2D6, CYP2E1, and CYP3A4 at concentrations of $306 \mu \mathrm{g} / \mathrm{mL}$ to $1660 \mu \mathrm{g} / \mathrm{mL}$ in vitro. [145]. On the contrary, aqueous extract of $H$. sabdariffa was shown not to have any significant inhibitory or inductive effects on CY P450 enzymes CYP1A1, CYP1A2, CYP2B1/2, CYP2E1, and CYP3A, and neither did it have any effects on the total CYP450 levels [146].

4.3. Cancer. Cancer cells often become simultaneously resistant to multiple drugs. The molecular basis of MDR is the overexpression of ATP-binding cassette $(\mathrm{ABC})$ transporters, an MDR1/ABCB1 gene encoding P-glycoprotein which effectively extrudes hydrophobic drugs out of cancer cells, effectively precluding their activity [147, 148]. From a clinical standpoint this phenomenon correlates positively with poor therapeutic outcomes [149]. This led to the concept of chemosensitization which involves the coadministration of a P-gp inhibitor with an anticancer drug in order to enhance intracellular anticancer drug accumulation via impairing the Pgp efflux function. Early generation P-gp inhibitors induced CYP3A4-mediated drug metabolism [150] and were associated with severe toxicities. Third-generation inhibitors appear to possess acceptable toxicity profiles but are yet to find proper clinical application $[151,152]$ thus necessitating a possible fallback to natural products such as African herbals. Several phytochemicals were tested in vitro and found to reverse MDR but data on safety and efficacy is insufficient [153]. Since P-gp plays an important role in the intestinal absorption, distribution to the central nervous system, and biliary/urinary excretion of drugs, potential interactions may cause altered absorption and bioavailability of P-gp substrates [52, 154]. In addition, numerous African plant extracts and their phytoconstituents were shown to possess intrinsic anticancer effects both in vitro and in vivo but the majority of investigations did not demonstrate significant P-gp or CYP modulation [155-157]. Furthermore, pleiotropic or broad spectrum drug resistance is not limited to $\mathrm{ABC}$ transporters alone; oncogenes and tumour suppressors can also confer drug resistance in addition to their role in carcinogenesis $[158,159]$.

4.3.1. P-gp Mediated Interactions. These herbs are characterised by limited intrinsic cytotoxicity to MDR tumours but are capable of resensitizing resistant cells to conventional cytotoxic agents via P-gp.

(1) Acokanthera oppositifolia (Common Poison Bush). This plant is native to Eastern and South Africa [160] where it is traditionally used as a highly effective arrow poison [161] $A$. oppositifolia contains cardiotonic steroids, acovenoside, and ouabain.

Its extracts exert considerable dose-dependent cytotoxicity towards both sensitive CCRF-CEM and P gp overexpressing CEM/ADR5000 leukemia cells [156] as well as towards TK10 renal cancer cells, MCF-7 breast, and UACC62 melanoma cells [162]. Ouabain is known to act by inhibiting $\mathrm{Na}+/ \mathrm{K}+$-ATPase leading to strong inotropic effects on the 
heart [163]. Cardiotonic steroids also inhibit the efflux function of P-glycoprotein and overcome MDR of tumour cells [164]. Saeed and group found that at lethal concentrations acovenoside A and ouabain did not reveal any statistically significant associations between cellular responsiveness to the two cardiotonic glycosides and $\mathrm{ABCB} 1$ expression and function. On the contrary, Brouillard et al. earlier reported that ouabain treatment led to the induction of MDR1 expression [165] leading the latter authors to hypothesize that this likely occurred at sublethal doses. Furthermore, Saeed and colleagues further documented an association between high $\mathrm{ABCC} 1$ expression and resistance to the two glycosides could not be established in the NCI cell line, and they concluded that $\mathrm{ABC}$ transporter had a limited role in the unresponsiveness of NCI cell line to acovenoside A and ouabain [156]. As such these contradictory findings require further in-depth investigation in order to ascertain actual interaction of these steroids with $\mathrm{ABC}$ transporters and the possible clinical implications thereafter.

(2) Annona senegalensis (Wild Custard Apple). It is native to tropical east and northeast, west and west-central, and southern Africa, as well as southern subtropical Africa. Stem bark and leaves are used for the treatment of skin cancer and leukemia [166].

In vitro leaf extracts of $A$. senegalensis show limited intrinsic cytotoxicity against various cell lines $[167$, 168]. Interestingly, its aporphine alkaloid, (-)-roemerine, increased the toxicity of vinblastine to MDR oral epidermoid carcinoma KB-V1 cells, possibly through the inhibition of substrate binding in P-gp, therefore decreasing cellular efflux of the anticancer drug [168]. Therefore further studies are required to validate the possible benefits of coadministration of these related compounds in chemotherapy.

(3) Euphorbia tuckeyana (Tortolho). E. tuckeyana is endemic in Cape Verde. The macrocyclic diterpenes of the jatrophane type, tuckeyanols A and B, and euphotuckeyanol, isolated from aerial parts of E. tuckeyana, were tested for P-gp modulating properties on human MDR1 gene-transfected and parental L5178 mouse lymphoma cell lines. All compounds were found to highly increase Rhodamine-123 retention in the cells by inhibiting the efflux pump activity mediated by Pgp, resulting in a reversal of MDR. This activity was concentration dependent and found to be more potent when compared with the positive control verapamil. These compounds also exhibited moderate antiproliferative activity on the two cell lines [169]. Their strong P-gp modulation on both human and murine MDR1 cell lines makes them good candidates for further clinical investigations.

(4) Mangifera indica (Mango). Originally from India, Mango is naturalised in tropical Africa. Folkloric uses include the treatment of fever, jaundice and liver disorders [170], and arthritis and type II diabetes [171]. Mangiferin, a xanthone glycoside, is a major bioactive constituent that has strong antioxidant, antilipid peroxidation, immunomodulation, cardiotonic, hypotensive, wound healing, and antidegenerative and antidiabetic activities [172].
When MCF-7, a model cell line for human mammary carcinoma, was incubated with doxorubicin for 10 days, it showed decreased sensitivity to the drug. The addition of mangiferin at concentration $50 \mu \mathrm{M}$ restored sensitivity to doxorubicin. Treatment of the cells with verapamil (positive control for P-gp and MRP inhibitor) and nelfinavir (positive control for BCRP) also achieved similar results. At this concentration, mangiferin showed a significant reduction of P-gp mRNA expressions but did not influence the mRNA expressions of MRP1 and BCRP suggesting that modulation of P-gp alone may be sufficient for mangiferin mediated tumour sensitization [173].

In vitro human hepatocytes treated with subcytotoxic concentrations of mangiferin showed concentration-dependent inhibition of five P 450 enzymes, that is, CYP1A2, CYP2A6, CYP2C6, CYP2D6, and CYP3A4 [174]. This may result in increased bioavailability and possibly toxicity of coadministered anticancers like vinca alkaloids and taxane alkaloids which are CYP3A4 substrates.

(5) Pycnanthus angolensis (African Nutmeg). African nutmeg is widely spread in tropical Africa. In traditional African medicine the sap was used to control bleeding. The bark was used as a poison antidote and a treatment for leprosy, anaemia, infertility, gonorrhea, and malaria.

The lignans (-)-dihydroguaiaretic acid and heliobuphthalmin were isolated from the chloroform extract of $P$. angolensis and tested against cancer cells expressing classical MDR phenotype. Heliobuphthalmin showed significant antiproliferative activities against the subline EPG85-257RDB that overexpresses MDR1/P-gp which was 8-fold more sensitive than the parental drug-sensitive cells. On the other hand (-)-dihydroguaiaretic acid showed a moderate activity against multidrug-resistant EPG85-257RNOV cells [175]. In addition, seven lignans either isolated from $P$. angolensis or obtained by derivatization were strong inducers of apoptosis of human hepatoma HuH-7 cells [176]. Therefore, heliobuphthalmin may be a promising candidate as a chemosensitizing agent for consideration in drug development.

(6) Sutherlandia frutescens (Cancer Bush). This plant is endemic to southern Africa and referred to as "cancer bush" because of the widespread use by the Khoisan and Zulu in treatment of internal cancers. Ethnomedically, it was also employed in treatment of influenza, wounds, pains, aches, and skin disorders [177]. Triterpenoid and flavonol glycosides (kaempferol and quercetin glycosides) have been isolated from S. frutescens $[178,179]$.

Extracts of $S$. frutescens have shown antiproliferation and apoptotic effect in breast cancer cells and cervical cancer cells [180-182]. Its actual mechanism of action remains largely unknown but in vitro Sutherlandia represses Hedgehogsignaling pathway in murine prostate cancer cells [183] as well as key molecules in the PI-3 K pathway in colon cancer cells [184].

Sutherlandia extract exerted inhibitory activity on the transport activities of intestinal P-gp with an $\mathrm{IC}_{50}$ $324.8 \mu \mathrm{g} / \mathrm{mL}$ but did not exert any inhibitory activity on the activity of BCRP [185] indicating that at high doses the extract 
may cause an increase in bioavailability of susceptible drugs. Interestingly, kaempferol markedly increased the sensitivity of the multidrug-resistant human cervical carcinoma KB-V1 cells to vinblastine and paclitaxel dose-dependently and also decreased the relative resistance of these anticancer drugs in KB-V1 cells [186].

In healthy male subjects, administration of S. frutescens tablets and then a single dose of atazanavir (a substrate of both intestinal P-gp and CYP3A4) caused a significant reduction in the bioavailability of atazanavir which may be attributable to a decrease in absorption and/or enhanced metabolism of atazanavir [187]. Since this drug is a substrate for both, we cannot conclude whether reduced bioavailability is attributable to the transporter or the enzyme. However, chronic dosing of Sutherlandia reduced the plasma levels of a single dose of nevirapine in rats, which correlated with an increase in the expression of CYP3A4 [188]. In vitro, Sutherlandia showed a concentration-dependent inhibition of CYP1A2, CYP2A6, CYP2B6, CYP2C8, CYP2C9, CYP2C19, and CYP3A4/5 [185]. Therefore, we expect that coadministration of this herb in sufficient doses and anticancers, the majority of which are CYP3A4, may result in increased bioavailability and possibly toxicity.

4.3.2. Non-P-gp Mediated Interactions. These herbs are characterised by significant intrinsic cytotoxicity to cancer cells mediated via a variety of molecular mechanisms exclusive of P-gp.

(1) Catharanthus roseus (Madagascar Periwinkle). Catharanthus roseus is native to Madagascar and is the source of cytotoxic vinca alkaloids like vincristine and vinblastine which are the second most used class of anticancers in conventional medicine [189]. Their cytotoxicity was reported to be impaired in MDR $[190,191]$. As a result several in vitro studies investigated the resensitization of MDR cells to vinblastine and are discussed above $[168,192,193]$. Although the authors reported beneficial findings, one needs to be cautious in extrapolating these to suggest resounding clinical advantages. Nevertheless, should future findings prove that benefits of chemosensitization with African herbals outweigh risks, then negative dose adjustment of anticancers may be necessary.

Repeated administration of vinblastine, which is standard practice in chemotherapy, increased both activity and gene expression of CYP3A4 in humans and mice [194]. As such the clearance of coadministered substrates of this enzyme may be increased thus compromising their plasma concentration possibly resulting in suboptimal clinical outcomes.

(2) Hypoxis hemerocallidea (African Potato). This herb belongs to the family Hypoxidaceae. It is indigenous to and grows widely in the southern Africa savanna grasslands [195]. The rootstock was widely used traditionally particularly in Zulu society for various chronic conditions, infections among other indications [196]. Contemporary uses in ACM today include the management of HIV/AIDS, arthritis, myalgic encephalomyelitis (ME), hypertension, asthma, diabetes mellitus, cancer, arthritis, psoriasis, tuberculosis, and epilepsy [197-199].
Hypoxoside is the major diglucoside isolated from the corms of this plant. Intragastrically, it is deconjugated by $\beta$ glucosidase to form the cytotoxic and lipophilic aglycone, rooperol, which is a potent inhibitor of leukotriene synthesis in polymorphonuclear leucocytes at concentrations of $1 \mu \mathrm{M}$ or less [200]. Substantial cytotoxicity against Murine BL6 and human UCT-Mel 1 melanoma cell lines was reported at $50 \mu \mathrm{g} / \mathrm{mL}$ in presence of $\beta$-glucosidase. [201]. Chloroform extracts of $H$. hemerocallidea and $H$. sobolifera were also cytotoxic against MCF-7, HeLa, and HT-29 cancer cells [202].

In vitro, water extracts of Hypoxis hemerocallidea showed no inhibitory activity against P-gp and BCRP at concentrations of up to $500 \mu \mathrm{g} / \mathrm{mL}$. However Fasinu et al. observed a concentration-dependent inhibition of CYP1A2, CYP2A6, CYP2B6, CYP2C8, CYP2C9, and CYP3A4/5 with the extract at concentrations of $100 \mu \mathrm{g} / \mathrm{mL}$ [203]. The herb is widely used in Africa as adjunct treatment in many chronic ailments and as such can alter pharmacokinetics of drugs such as calcium channel blockers and chemotherapeutic agents stated above by increasing plasma concentrations to above safety margins. Fasinu et al. performed single dose experiments which may not be used to accurately predict clinical outcomes because chronic use of the herb is the norm and may thus predispose patients to even graver potential CYP interactions.

\section{Clinical Consequences of Modulation of Cytochrome P450 and P-Glycoprotein}

5.1. Cytochrome P450. T. foenum, K. crenata, N. sativa, $P$. amarus, L. sativum, A. herba-alba, H. sabdariffa, $M$. indica, $S$. frutescens, and $H$. hemerocallidea have shown potential to inhibit CYP3A4. In fact, most of the herbs under consideration have an effect on this particular CYP. This is as expected because, as indicated earlier, CYP3A4 is the most critical enzyme in metabolism of drugs commonly used in management of NCDs. Its inhibition therefore means a higher possibility of HDIs and consequent precipitation of adverse drug events by these drugs.

Sulphonylureas like glibenclamide are mostly metabolized by CYP3A4 [106, 204] and so are thiazolidinediones including pioglitazone and troglitazone [205]. As a precaution, the doses of the respective OADs for patients taking these herbs need to be adjusted downwards in order to achieve the desired glycaemic parameters.

Repeated administration of $A$. herba-alba or $H$. sabdariffa incorporated herbal remedies with CYP3A4 substrates like calcium channel blockers, losartan, and nateglinide [206] could trigger untoward effects. Thus, coadministration with amlodipine may decrease the metabolism of amlodipine, where a higher plasma concentration and a potential side effect such as hypotension are conceivable. Correspondingly, nateglinide is partly metabolized (30\%) by CYP3A4 [207] and could be affected by inhibitors of CYP3A4. Furthermore, the majority of currently prescribed antineoplastic agents are metabolized by CYP3A4, for instance, docetaxel, erlotinib, imatinib, irinotecan, paclitaxel, and vinca alkaloids [208].

Some herbs may have an induction/inhibition effect on CYP. A good example is $N$. sativa. When $N$. sativa was coadministered with cyclosporine in an animal model, the oral 
bioavailability of cyclosporine was significantly reduced suggestive of the possibility that $N$. sativa causes induction of intestinal P-gp and/or CYP3A4 [115]. The ability of $N$. sativa to either induce or inhibit CYP3A4 and the potential for HDIs thereof, especially with regard to OADs, may need to be studied further.

CYP2C8 and CYP2C9 are principal metabolizers of several drugs used for NCDs especially OADs. T. foenum, $L$. sativum, $P$. amarus, $H$. sabdariffa, $S$. frutescens, and $H$. hemerocallidea among others inhibit CYP2C8 and/2C9. This is a potential interaction point especially in diabetes patients on OADs because glitazones like rosiglitazone are largely metabolized by CYP2C8 and to a lesser extent by CYP2C9 [209]. This means that diabetes patients using glitazones and the candidate herbs concurrently may be at risk of hypoglycaemia as well as side effects associated with glitazones.

Likewise, CYP2C19 is involved in metabolism of the tolbutamide (a sulphonylurea) as well as antihypertensives like propranolol [210]. It is inhibited by, among others, K. crenata and S. frutescens. Hence, in diabetic patients with comorbid HTN on a combination of these medications and the stated herbs, there may be a risk of hypoglycaemia and inadequate reduction in blood pressure.

CYP2D6 is important in metabolism of some antihypertensives such as propranolol, alprenolol, and verapamil [211]. T. foenum, L. sativum, A. herba-alba, and H. sabdariffa have all been shown to be inhibitors of CYP2D6 and this is a potential source of HDIs. As a result, they possess the likelihood of inducing synergism or an increased bioavailability of the said drugs due to reasons as have been noted. Beta-blockers like propranolol have a narrow therapeutic window and as such caution is necessary and dose adjustment may be of help. CYP2D6 inhibition may however be of little consequence in patients on OADs as it plays a minor role in metabolism of these types of drugs.

5.2. P-Glycoprotein. The influence of P-gp on cancer management is two-pronged. At the intestinal lumen P-gp extrudes susceptible drugs back into the lumen. As a consequence their bioavailability may be diminished. S. frutescens is one herb that has been tested against intestinal P-gp and shown to inhibit it if sufficient concentrations are achieved albeit under in vitro conditions. The expected clinical outcome of this interaction would be increased bioavailability and possibly toxicity in view of the fact that most anticancers have a narrow therapeutic window [212]. Nonetheless, should the intrinsic cytotoxicity of such herbs be significant, then they could be utilized as adjunct therapies with conventional anticancers whose dose may be adjusted downwards. However extensive studies are required to validate this proposition.

At the tumour cell membrane chemosensitization can be achieved by inhibiting P-gp. Several African herbals were confirmed to inhibit this transporter thus improving sensitivity of cancer cells to a myriad of conventional anticancers like paclitaxel, doxorubicin, and vinca alkaloids which also happen to be the second most used anticancers and are derived from the African plant Catharanthus roseus. Compounds like tuckeyanols and heliobuphthalmin show strong reversal of resistance in cells expressing MDR1/P gp genes and are therefore good candidates for further drug development. Clinically, they could be coadministered with P-gp substrates, where P-gp inhibition would result in dug accumulation to cytotoxic concentrations and ultimately improve therapeutic outcomes.

Not all herbs were reported to inhibit MDR1 expression. Brouillard et al. reported that ouabain, a compound in Acokanthera oppositifolia, can induce MDR expression in vitro. The clinical implications of this would be catastrophic if the herb was coadministered with anticancer drugs. On the contrary, Saeed et al. reported that there was no correlation between cellular responses to ouabain by cancer cells and $\mathrm{ABCB} 1$ expression and function. Interestingly several authors reported that there was a dose-dependent cytotoxicity of extracts of A. oppositifolia to both sensitive and MDR resistant cells. These contradictory findings point to the need for more extensive research in this area.

In addition, individual variations in clinical outcomes may be influenced by P-gp genetic polymorphisms. For instance, the association of wild-type ABCB1 (P-gp) CGC haplotype with a slower clearance may suggest that, in individuals who possess this P-gp genetic polymorph, P-gp-mediated transport of anticancers is less significant compared to those who exhibit other P-gp polymorphs. These individuals may therefore be at a lower risk of toxicity mediated through P-gp inhibition at the intestine and may also be less responsive to P-gp mediated chemosensitization by the named herbs.

\section{Conclusion}

When African herbals that regulate either CYP or P-gp activity were coadministered with conventional drugs they could either synergize or antagonize their activity in addition to exerting their own intrinsic toxicity. As a result, therapeutic drug monitoring systems are needed to examine the extent and severity of such interactions. Nevertheless, beneficial interactions can be medically exploited. For example, pervilleine and tuckeyanols can reverse MDR in tumours. Similarly, when coadministered with $H$. sabdariffa and $T$. foenum-graecum, HCTZ and glibenclamide, respectively, are potentiated and can be administered at lower doses thus reducing their inherent toxicities. Subsequently, compliance too may be enhanced [92].

Our work relied heavily on findings from in vitro studies which tend to have a low predictive value because literature was scarce. Therefore, more clinical research effort needs to be expended in this field in order to generate accurate and reliable data so that health practitioners can be equipped with the necessary skills to anticipate and manage HDIs accordingly and advice patients on traditional medicine use.

Another challenge in Africa emanates from the weak policy and regulatory frameworks regarding traditional medicine [213]. This too can be addressed in part by furthering research that can assist governments to design interventions that adequately regulate traditional medicine practice and possibly integrate it into mainstream healthcare systems. 


\section{Competing Interests}

There is no conflict of interests whatsoever by any author of this article.

\section{Acknowledgments}

This paper was supported by National Natural Science Foundation of China (NSFC) [no. 81373890 and no. 81430096]; the Open Topic Fund for State Key Laboratory of Bioactive Substance and Function of Natural Medicines [no. GTZK201514]; and the Program for Changjiang Scholars and Innovative Research Team in University (PCSIRT) [no. IRT_14R41].

\section{References}

[1] R. Hermann and O. Von Richter, "Clinical evidence of herbal drugs as perpetrators of pharmacokinetic drug interactions," Planta Medica, vol. 78, no. 13, pp. 1458-1477, 2012.

[2] M. Ekor, "The growing use of herbal medicines: issues relating to adverse reactions and challenges in monitoring safety," Frontiers in Pharmacology, vol. 4, article 177, 2014.

[3] G. M. Cragg and D. J. Newman, "Natural products: a continuing source of novel drug leads," Biochimica et Biophysica ActaGeneral Subjects, vol. 1830, no. 6, pp. 3670-3695, 2013.

[4] WHO, Legal Status of Traditional Medicine and Complementar, 2001.

[5] G. Y. Yeh, R. B. Davis, and R. S. Phillips, "Use of complementary therapies in patients with cardiovascular disease," The American Journal of Cardiology, vol. 98, no. 5, pp. 673-680, 2006.

[6] B.-E. Van Wyk, H. de Wet, and F. R. Van Heerden, "An ethnobotanical survey of medicinal plants in the southeastern Karoo, South Africa," South African Journal of Botany, vol. 74, no. 4, pp. 696-704, 2008.

[7] S. Bent, "Herbal medicine in the United States: review of efficacy, safety, and regulation: grand rounds at University of California, San Francisco Medical Center," Journal of General Internal Medicine, vol. 23, no. 6, pp. 854-859, 2008.

[8] A. O. Ogbera, O. Dada, F. Adeleye, and P. I. Jewo, "Complementary and alternative medicine use in diabetes mellitus," West African Journal of Medicine, vol. 29, no. 3, pp. 158-162, 2010.

[9] O. C. Amira and N. U. Okubadejo, "Frequency of complementary and alternative medicine utilization in hypertensive patients attending an urban tertiary care centre in Nigeria," BMC Complementary and Alternative Medicine, vol. 7, article 30, 2007.

[10] E. R. Ezeome and A. N. Anarado, "Use of complementary and alternative medicine by cancer patients at the University of Nigeria Teaching Hospital, Enugu, Nigeria," BMC Complementary and Alternative Medicine, vol. 7, no. 1, article 28, 2007.

[11] R. Nowack, "Review Article: Cytochrome P450 enzyme, and transport protein mediated herb-drug interactions in renal transplant patients: grapefruit juice, St John's Wort-and beyond! (Review Article)," Nephrology, vol. 13, no. 4, pp. 337$347,2008$.

[12] A. A. Izzo and E. Ernst, "Interactions between herbal medicines and prescribed drugs," Drugs, vol. 69, no. 13, pp. 1777-1798, 2009.

[13] B. J. Gurley, E. K. Fifer, and Z. Gardner, "Pharmacokinetic herbdrug interactions (part 2): drug interactions involving popular botanical dietary supplements and their clinical relevance," Planta Medica, vol. 78, no. 13, pp. 1490-1514, 2012.

[14] S. J. Brantley, T. N. Graf, N. H. Oberlies, and M. F. Paine, "A systematic approach to evaluate herb-drug interaction mechanisms: investigation of milk thistle extracts and eight isolated constituents as CYP3A inhibitors," Drug Metabolism and Disposition, vol. 41, no. 9, pp. 1662-1670, 2013.

[15] S.-B. Kim, I.-S. Yoon, K.-S. Kim et al., "In vitro and in vivo evaluation of the effect of puerarin on hepatic cytochrome P450-mediated drug metabolism," Planta Medica, vol. 80, no. 7, pp. 561-567, 2014.

[16] I. Meijerman, J. H. Beijnen, and J. H. M. Schellens, "Herb-drug interactions in oncology: focus on mechanisms of induction," The Oncologist, vol. 11, no. 7, pp. 742-752, 2006.

[17] P. Gardiner, R. E. Graham, A. T. R. Legedza, D. M. Eisenberg, and R. S. Phillips, "Factors associated with dietary supplement use among prescription medication users," Archives of Internal Medicine, vol. 166, no. 18, pp. 1968-1974, 2006.

[18] J. Kennedy, C.-C. Wang, and C.-H. Wu, "Patient disclosure about herb and supplement use among adults in the US," Evidence-Based Complementary and Alternative Medicine, vol. 5, no. 4, pp. 451-456, 2008.

[19] C. Tarirai, A. M. Viljoen, and J. H. Hamman, "Herb-drug pharmacokinetic interactions reviewed," Expert Opinion on Drug Metabolism \& Toxicology, vol. 6, no. 12, pp. 1515-1538, 2010.

[20] L. Brown, O. Heyneke, D. Brown, J. P. H. van Wyk, and J. H. Hamman, "Impact of traditional medicinal plant extracts on antiretroviral drug absorption," Journal of Ethnopharmacology, vol. 119, no. 3, pp. 588-592, 2008.

[21] H. Tunstall-Pedoe, "Preventing chronic diseases. A vital investment: WHO global report. Geneva: World Health Organization, 2005. pp 200. CHF 30.00. ISBN 924 1563001,' International Journal of Epidemiology, vol. 35, no. 4, p. 1107, 2006.

[22] G. Danaei, S. V. Hoorn, A. D. Lopez, C. J. L. Murray, and M. Ezzati, "Causes of cancer in the world: comparative risk assessment of nine behavioural and environmental risk factors," The Lancet, vol. 366, no. 9499, pp. 1784-1793, 2005.

[23] D. H. Roukos, "Genome-wide association studies: how predictable is a person's cancer risk?" Expert Review of Anticancer Therapy, vol. 9, no. 4, pp. 389-392, 2009.

[24] J. S. Oliver, "United States, Africa, Caribbean collaboration: strengths and opportunities for global cancer research," in Proceedings of the Sigma Theta Tau International's 27th International Nursing Research Congress (STTI '16), Utrecht, The Netherlands, 2016.

[25] M. A. Weber, E. L. Schiffrin, W. B. White et al., "Clinical practice guidelines for the management of hypertension in the community," The Journal of Clinical Hypertension, vol. 16, no. 1, pp. 14-26, 2014.

[26] D. Bradshaw, P. Groenewald, R. Laubscher et al., "Initial burden of disease estimates for South Africa, 2000," South African Medical Journal, vol. 93, no. 9, pp. 682-688, 2003.

[27] A. P. Kengne and B. M. Mayosi, "Readiness of the primary care system for non-communicable diseases in sub-Saharan Africa," The Lancet Global Health, vol. 2, no. 5, pp. e247-e248, 2014.

[28] C. J. Murray, T. Vos, and R. Lozano, "Disability-adjusted life years (DALYs) for 291 diseases and injuries in 21 regions, 19902010: a systematic analysis for the Global Burden of Disease Study 2010," The Lancet, vol. 380, no. 859, pp. 2197-2223, 2010.

[29] J. E. Shaw, R. A. Sicree, and P. Z. Zimmet, "Global estimates of the prevalence of diabetes for 2010 and 2030," Diabetes Research and Clinical Practice, vol. 87, no. 1, pp. 4-14, 2010. 
[30] C. M. M. Lawes, S. Vander Hoorn, M. R. Law, P. Elliott, S. MacMahon, and A. Rodgers, "Blood pressure and the global burden of disease 2000. Part 1: estimates of blood pressure levels," Journal of Hypertension, vol. 24, no. 3, pp. 413-422, 2006.

[31] WHO Regional Office for Africa, The Health of the People: The African Regional Health Report, World Health Organization, 2006.

[32] B. M. Mayosi, “The 10 'Best Buys' to combat heart disease, diabetes and stroke in Africa," Heart, vol. 99, no. 14, pp. 973974, 2013.

[33] F. Bray, J.-S. Ren, E. Masuyer, and J. Ferlay, "Global estimates of cancer prevalence for 27 sites in the adult population in 2008," International Journal of Cancer, vol. 132, no. 5, pp. 1133-1145, 2013.

[34] L. A. Torre, F. Bray, R. L. Siegel, J. Ferlay, J. Lortet-Tieulent, and A. Jemal, “Global cancer statistics, 2012," CA Cancer Journal for Clinicians, vol. 65, no. 2, pp. 87-108, 2015.

[35] K. S. Ogle, G. M. Swanson, N. Woods, and F. Azzouz, "Cancer and comorbidity: redefining chronic diseases," Cancer, vol. 88, no. 3, pp. 653-663, 2000.

[36] A. M. Gerber, R. Botes, A. Mostert, A. Vorster, and E. Buskens, "A cohort study of elderly people in Bloemfontein, South Africa, to determine health-related quality of life and functional abilities," South African Medical Journal, vol. 106, no. 3, pp. 298301, 2016.

[37] N. Folb, V. Timmerman, N. S. Levitt et al., "Multimorbidity, control and treatment of noncommunicable diseases among primary healthcare attenders in the Western Cape, South Africa," South African Medical Journal, vol. 105, no. 8, pp. 642647, 2015.

[38] S. Zhou, Y. Gao, W. Jiang, M. Huang, A. Xu, and J. W. Paxton, "Interactions of herbs with cytochrome P450," Drug Metabolism Reviews, vol. 35, no. 1, pp. 35-98, 2003.

[39] D. E. Amacher, "The effects of cytochrome P450 induction by xenobiotics on endobiotic metabolism in pre-clinical safety studies," Toxicology Mechanisms and Methods, vol. 20, no. 4, pp. 159-166, 2010.

[40] S. Rendic and F. J. Di Carlo, "Human cytochrome P450 enzymes: a status report summarizing their reactions, substrates, inducers, and inhibitors," Drug Metabolism Reviews, vol. 29, no. 1-2, pp. 413-580, 1997.

[41] J.-J. Wu, C.-Z. Ai, Y. Liu et al., "Interactions between phytochemicals from traditional Chinese medicines and human cytochrome P450 enzymes," Current Drug Metabolism, vol. 13, no. 5, pp. 599-614, 2012.

[42] H. Zhang, D. Cui, B. Wang et al., "Pharmacokinetic drug interactions involving $17 \alpha$-ethinylestradiol: a new look at an old drug," Clinical Pharmacokinetics, vol. 46, no. 2, pp. 133-157, 2007.

[43] O. Pelkonen, M. Turpeinen, J. Hakkola, P. Honkakoski, J. Hukkanen, and H. Raunio, "Inhibition and induction of human cytochrome P450 enzymes: current status," Archives of Toxicology, vol. 82, no. 10, pp. 667-715, 2008.

[44] P. B. Watkins, S. A. Wrighton, E. G. Schuetz, D. T. Molowa, and P. S. Guzelian, "Identification of glucocorticoid-inducible cytochromes P-450 in the intestinal mucosa of rats and man," The Journal of Clinical Investigation, vol. 80, no. 4, pp. 1029-1036, 1987.

[45] A. H. Schinkel and J. W. Jonker, "Mammalian drug efflux transporters of the ATP binding cassette (ABC) family: an overview," Advanced Drug Delivery Reviews, vol. 55, no. 1, pp. 3-29, 2003.
[46] Y. Romsicki and F. J. Sharom, "The ATPase and ATP-binding functions of P-glycoprotein," European Journal of Biochemistry, vol. 256, no. 1, pp. 170-178, 1998.

[47] M. M. R. De Maat, G. Corine Ekhart, A. D. R. Huitema, C. H. W. Koks, J. W. Mulder, and J. H. Beijnen, "Drug interactions between antiretroviral drugs and comedicated agents," Clinical Pharmacokinetics, vol. 42, no. 3, pp. 223-282, 2003.

[48] S.-F. Zhou, "Structure, function and regulation of Pglycoprotein and its clinical relevance in drug disposition," Xenobiotica, vol. 38, no. 7-8, pp. 802-832, 2008.

[49] M. Takano, R. Yumoto, and T. Murakami, "Expression and function of efflux drug transporters in the intestine," Pharmacology and Therapeutics, vol. 109, no. 1-2, pp. 137-161, 2006.

[50] S. Katragadda, B. Budda, B. S. Anand, and A. K. Mitra, "Role of efflux pumps and metabolising enzymes in drug delivery," Expert Opinion on Drug Delivery, vol. 2, no. 4, pp. 683-705, 2005.

[51] S. B. Syed and M. S. Coumar, "P-glycoprotein mediated multidrug resistance reversal by phytochemicals: a review of SAR \& future perspective for drug design," Current Topics in Medicinal Chemistry, vol. 16, no. 22, pp. 2484-2508, 2016.

[52] S. Zhou, L. Y. Lim, and B. Chowbay, "Herbal modulation of P-glycoprotein,” Drug Metabolism Reviews, vol. 36, no. 1, pp. 57-104, 2004.

[53] J. Hunter and B. H. Hirst, "Intestinal secretion of drugs. The role of P-glycoprotein and related drug efflux systems in limiting oral drug absorption," Advanced Drug Delivery Reviews, vol. 25, no. 2-3, pp. 129-157, 1997.

[54] S. Marchetti, R. Mazzanti, J. H. Beijnen, and J. H. M. Schellens, "Concise review: clinical relevance of drug-drug and herbdrug interactions mediated by the $\mathrm{ABC}$ transporter $\mathrm{ABCB} 1$ (MDR1, P-glycoprotein)," Oncologist, vol. 12, no. 8, pp. 927-941, 2007.

[55] S. Gupta, "P-glycoprotein expression and regulation: agerelated changes and potential effects on drug therapy," Drugs \& Aging, vol. 7, no. 1, pp. 19-29, 1995.

[56] S. Gollapudi, M. Reddy, P. Gangadharam, T. Tsuruo, and S. Gupta, "Mycobacterium tuberculosis induces expression of Pglycoprotein in promonocytic U1 cells chronically infected with HIV type 1," Biochemical and Biophysical Research Communications, vol. 199, no. 3, pp. 1181-1187, 1994.

[57] A. Ahmadu, A. Abdulkarim, R. Grougnet et al., "Two new peltogynoids from Acacia nilotica Delile with kinase inhibitory activity," Planta Medica, vol. 76, no. 5, pp. 458-460, 2010.

[58] R. Singh, B. Singh, S. Singh, N. Kumar, S. Kumar, and S. Arora, "Anti-free radical activities of kaempferol isolated from Acacia nilotica (L.) Willd. Ex. Del.," Toxicology in Vitro, vol. 22, no. 8, pp. 1965-1970, 2008.

[59] S. Deferme, A. Kamuhabwa, C. Nshimo, P. De Wittez, and P. Augustijns, "Screening of Tanzanian plant extracts for their potential inhibitory effect on P-glycoprotein mediated efflux," Phytotherapy Research, vol. 17, no. 5, pp. 459-464, 2003.

[60] A. Agbonon, K. Eklu-Gadegbeku, K. Aklikokou et al., "In vitro inhibitory effect of West African medicinal and food plants on human cytochrome P450 3A subfamily," Journal of Ethnopharmacology, vol. 128, no. 2, pp. 390-394, 2010.

[61] E. O. Ajaiyeoba and O. Ekundayo, "Essential oil constituents of Aframomum melegueta (Roscoe) K. Schum. seeds (alligator pepper) from Nigeria," Flavour and Fragrance Journal, vol. 14, no. 2, pp. 109-111, 1999. 
[62] R. M. P. Gutierrez, E. G. Baez, M. del Socorro López Cortez, and S. A. Cárdenas, "Extracts of bixa inhibit glycation and AGEs formation in vitro," Journal of Medicinal Plants Research, vol. 5, no. 6, pp. 942-948, 2011.

[63] C. Jewell and N. M. O’Brien, "Effect of dietary supplementation with carotenoids on xenobiotic metabolizing enzymes in the liver, lung, kidney and small intestine of the rat," British Journal of Nutrition, vol. 81, no. 3, pp. 235-242, 1999.

[64] T. Nabekura, S. Kamiyama, and S. Kitagawa, "Effects of dietary chemopreventive phytochemicals on P-glycoprotein function," Biochemical and Biophysical Research Communications, vol. 327, no. 3, pp. 866-870, 2005.

[65] E. F. Oga, S. Sekine, Y. Shitara, and T. Horie, "P-glycoprotein mediated efflux in Caco-2 cell monolayers: the influence of herbals on digoxin transport," Journal of Ethnopharmacology, vol. 144, no. 3, pp. 612-617, 2012.

[66] M. Rodrigues, G. Alves, J. Francisco, A. Fortuna, and A. Falcão, "Herb-drug pharmacokinetic interaction between carica papaya extract and amiodarone in rats," Journal of Pharmacy and Pharmaceutical Sciences, vol. 17, no. 3, pp. 302-315, 2014.

[67] L. Tona, K. Kambu, N. Ngimbi, K. Cimanga, and A. J. Vlietinck, "Antiamoebic and phytochemical screening of some Congolese medicinal plants," Journal of Ethnopharmacology, vol. 61, no. 1, pp. 57-65, 1998.

[68] N. M. Piero, M. N. Joan, K. M. Cromwell et al., "Hypoglycemic activity of some kenyan plants traditionally used to manage diabetes mellitus in eastern province," Journal of Diabetes \& Metabolism, vol. 2, article 8, 2011.

[69] W. Bedada, F. De Andrés, E. Engidawork et al., "The psychostimulant khat (Catha edulis) inhibits CYP2D6 enzyme activity in humans," Journal of Clinical Psychopharmacology, vol. 35, no. 6, pp. 694-699, 2015.

[70] J. Savai, A. Varghese, N. Pandita, and M. Chintamaneni, "Investigation of CYP3A4 and CYP2D6 interactions of Withania somnifera and centella asiatica in human liver microsomes," Phytotherapy Research, vol. 29, no. 5, pp. 785-790, 2015.

[71] Y. Pan, B. A. Abd-Rashid, Z. Ismail et al., "In vitro modulatory effects on three major human cytochrome P450 enzymes by multiple active constituents and extracts of Centella asiatica," Journal of Ethnopharmacology, vol. 130, no. 2, pp. 275-283, 2010.

[72] N. M. M. Shalaby, H. I. Abd-Alla, H. H. Ahmed, and N. Basoudan, "Protective effect of Citrus sinensis and Citrus aurantifolia against osteoporosis and their phytochemical constituents," Journal of Medicinal Plants Research, vol. 5, no. 4, pp. 579-588, 2011.

[73] J. Cao, L. Zheng, L. Ji, D. Lu, Y. Peng, and J. Zheng, "Mechanismbased inactivation of cytochrome P450 2B6 by isoimperatorin," Chemico-Biological Interactions, vol. 226, pp. 23-29, 2015.

[74] S. Malhotra, D. G. Bailey, M. F. Paine, and P. B. Watkins, "Seville orange juice-felodipine interaction: comparison with dilute grapefruit juice and involvement of furocoumarins," Clinical Pharmacology \& Therapeutics, vol. 69, no. 1, pp. 14-23, 2001.

[75] H. Takanaga, A. Ohnishi, S. Yamada et al., "Polymethoxylated flavones in orange juice are inhibitors of P-glycoprotein but not cytochrome P450 3A4," Journal of Pharmacology and Experimental Therapeutics, vol. 293, no. 1, pp. 230-236, 2000.

[76] T. Nabekura, T. Yamaki, and S. Kitagawa, "Effects of chemopreventive citrus phytochemicals on human P-glycoprotein and multidrug resistance protein 1," European Journal of Pharmacology, vol. 600, no. 1-3, pp. 45-49, 2008.

[77] K. Azuma, M. Nakayama, M. Koshioka et al., "Phenolic antioxidants from the leaves of Corchorus olitorius L.," Journal of
Agricultural and Food Chemistry, vol. 47, no. 10, pp. 3963-3966, 1999.

[78] S. Nwozo, O. Adaramoye, and E. Ajaiyeoba, "Oral administration of extract from Curcuma longa lowers blood glucose and attenuates alloxan-induced hyperlipidemia in diabetic rabbits," Pakistan Journal of Nutrition, vol. 8, no. 5, pp. 625-628, 2009.

[79] P. Neerati, R. Karan, and J. R. Kanwar, "Influence of curcumin on pioglitazone metabolism and $\mathrm{Pk} / \mathrm{Pd}$ : diabetes mellitus," Journal of Diabetes \& Metabolism, vol. 1, no. S6, 2013.

[80] R. Appiah-Opong, J. N. M. Commandeur, B. van VugtLussenburg, and N. P. E. Vermeulen, "Inhibition of human recombinant cytochrome P450s by curcumin and curcumin decomposition products," Toxicology, vol. 235, no. 1-2, pp. 8391, 2007.

[81] Y. Chen, W.-H. Liu, B.-L. Chen et al., "Plant polyphenol curcumin significantly affects CYPIA2 and CYP2A6 activity in healthy, male Chinese volunteers," Annals of Pharmacotherapy, vol. 44, no. 6, pp. 1038-1045, 2010.

[82] C. Ampasavate, U. Sotanaphun, P. Phattanawasin, and N. Piyapolrungroj, "Effects of Curcuma spp. on P-glycoprotein function," Phytomedicine, vol. 17, no. 7, pp. 506-512, 2010.

[83] H. A. Abdelgadir and J. Van Staden, "Ethnobotany, ethnopharmacology and toxicity of Jatropha curcas L. (Euphorbiaceae): a review," South African Journal of Botany, vol. 88, pp. 204-218, 2013.

[84] J. M. Dalziel, The useful plants of west tropical Africa, The useful plants of West Tropical Africa, 1937.

[85] A. C. Adebajo and J. Reisch, "Minor furocoumarins of Murraya koenigii," Fitoterapia, vol. 71, no. 3, pp. 334-337, 2000.

[86] A. C. Adebajo, G. Olayiwola, J. E. Verspohl et al., "Evaluation of the ethnomedical claims of Murraya koenigii," Pharmaceutical Biology, vol. 42, no. 8, pp. 610-620, 2004.

[87] S. Pandit, P. K. Mukherjee, K. Mukherjee et al., "Cytochrome P450 inhibitory potential of selected Indian spices-possible food drug interaction," Food Research International, vol. 45, no. 1, pp. 69-74, 2012.

[88] A. O. Ogunbinu, I. A. Ogunwande, G. Flamini, and P. L. Cioni, "Volatile compounds of Persea americana Mill from Nigeria," Journal of Essential Oil-Bearing Plants, vol. 10, no. 2, pp. 133-138, 2007.

[89] T. Nabekura, T. Yamaki, K. Ueno, and S. Kitagawa, "Inhibition of P-glycoprotein and multidrug resistance protein 1 by dietary phytochemicals," Cancer Chemotherapy and Pharmacology, vol. 62, no. 5, pp. 867-873, 2008.

[90] O. O. Babalola, J. I. Anetor, and F. A. Adeniyi, "Amelioration of carbon tetrachloride-induced hepatotoxicity by terpenoid extract from leaves of Vernonia amydgalina," African Journal of Medicine and Medical Sciences, vol. 30, no. 1-2, pp. 91-93, 2001.

[91] S. Skalli, A. Zaid, and R. Soulaymani, "Drug interactions with herbal medicines," Therapeutic Drug Monitoring, vol. 29, no. 6, pp. 679-686, 2007.

[92] W. Cordier and V. Steenkamp, "Drug interactions in African herbal remedies," Drug Metabolism and Drug Interactions, vol. 26, no. 2, pp. 53-63, 2011.

[93] P. Zimmet, K. G. M. M. Alberti, and J. Shaw, "Global and societal implications of the diabetes epidemic," Nature, vol. 414, no. 6865, pp. 782-787, 2001.

[94] WHO, World Health Organization Fact Sheet Number 312, World Health Organization, Geneva, Switzerland, 2006.

[95] L. L. Brunton, B. Chabner, and B. C. Knollmann, Goodman \& Gilman's the Pharmacological Basis of Therapeutics, vol. 12, McGraw-Hill Medical, New York, NY, USA, 2011. 
[96] G. C. Mannino and G. Sesti, "Individualized therapy for type 2 diabetes," Molecular Diagnosis \& Therapy, vol. 16, no. 5, pp. 285-302, 2012.

[97] M. Al-Habori and A. Raman, "Antidiabetic and hypocholesterolaemic effects of fenugreek," Phytotherapy Research, vol. 12, no. 4, pp. 233-242, 1998.

[98] G. Y. Yeh, D. M. Eisenberg, T. J. Kaptchuk, and R. S. Phillips, "Systematic review of herbs and dietary supplements for glycemic control in diabetes," Diabetes Care, vol. 26, no. 4, pp. 1277-1294, 2003.

[99] M. Shang, S. Cai, and X. Wang, "Analysis of amino acids in Trigonella foenumgraecum seeds," Journal of Chinese medicinal materials, vol. 21, no. 4, pp. 188-190, 1998.

[100] B. Bin-Hafeez, R. Haque, S. Parvez, S. Pandey, I. Sayeed, and S. Raisuddin, "Immunomodulatory effects of fenugreek (Trigonella foenum graecum L.) extract in mice," International Immunopharmacology, vol. 3, no. 2, pp. 257-265, 2003.

[101] T. Zia, S. N. Hasnain, and S. K. Hasan, "Evaluation of the oral hypoglycaemic effect of Trigonella foenum-graecum L. (methi) in normal mice," Journal of Ethnopharmacology, vol. 75, no. 2-3, pp. 191-195, 2001.

[102] F. Al-Jenoobi, H. M. Korashy, A. Ahad et al., "Potential inhibitory effect of herbal medicines on rat hepatic cytochrome P450 2D gene expression and metabolic activity," Die Pharmazie, vol. 69, no. 11, pp. 799-803, 2014.

[103] F. I. Al-Jenoobi, A. A. Al-Thukair, M. A. Alam et al., "Effect of Trigonella foenum-graecum L. on Metabolic Activity of CYP2D6 and CYP3A4," Forschende Komplementarmedizin, vol. 22, no. 3, pp. 180-184, 2015.

[104] H. M. Korashy, F. I. Al-Jenoobi, M. Raish et al., "Impact of herbal medicines like nigella sativa, trigonella foenum-graecum, and ferula asafoetida, on cytochrome P450 2C11 gene expression in rat liver," Drug Research, vol. 65, no. 7, pp. 366-372, 2014.

[105] M. F. Al-Ajmi, "The effect of fenugreek on the bioavailability of glibenclamide in normal beagle dogs," African Journal of Pharmacy and Pharmacology, vol. 5, no. 6, pp. 671-677, 2011.

[106] V. K. Manda, B. Avula, Z. Ali et al., "Characterization of in vitro ADME properties of diosgenin and dioscin from Dioscorea villosa," Planta Medica, vol. 79, no. 15, pp. 1421-1428, 2013.

[107] E. Adjanohoun, "Traditional medicine and pharmacopoeia: contribution to ethnobotanical and floristic studies in Cameroon," Tech. Rep., Scientific, Technical, and Research Commission of the Organization of African Unity, Lagos, Nigeria, 1996.

[108] R. Kamgang, R. Youmbi Mboumi, A. Foyet Fondjo, M. A. Fokam Tagne, G. P. R. Mengue N'dillé, and J. Ngogang Yonkeu, "Antihyperglycaemic potential of the water-ethanol extract of Kalanchoe crenata (Crassulaceae)," Journal of Natural Medicines, vol. 62, no. 1, pp. 34-40, 2008.

[109] C. Awortwe, V. K. Manda, C. Avonto et al., "In vitro evaluation of reversible and time-dependent inhibitory effects of kalanchoe crenata on CYP2C19 and CYP3A4 activities," Drug Metabolism Letters, vol. 9, no. 1, pp. 48-62, 2015.

[110] M. A. Khan, "Chemical composition and medicinal properties of Nigella sativa Linn.," Inflammopharmacology, vol. 7, no. 1, pp. 15-35, 1999.

[111] A.-U. H. Gilani, Q. Jabeen, and M. A. U. Khan, "A review of medicinal uses and pharmacological activities of Nigella sativa," Pakistan Journal of Biological Sciences, vol. 7, no. 4, pp. 441-451, 2004.
[112] A. Al-Hader, M. Aqel, and Z. Hasan, "Hypoglycemic effects of the volatile oil of Nigella sativa seeds," International Journal of Pharmacognosy, vol. 31, no. 2, pp. 96-100, 1993.

[113] B. Meddah, R. Ducroc, M. El Abbes Faouzi et al., "Nigella sativa inhibits intestinal glucose absorption and improves glucose tolerance in rats," Journal of Ethnopharmacology, vol. 121, no. 3, pp. 419-424, 2009.

[114] F. I. Al-Jenoobi, A. A. Al-Thukair, F. A. Abbas et al., "Effect of black seed on dextromethorphan O- and N-demethylation in human liver microsomes and healthy human subjects," Drug Metabolism Letters, vol. 4, no. 1, pp. 51-55, 2010.

[115] F. I. Al-Jenoobi, S. A. Al-Suwayeh, I. Muzaffar et al., "Effects of Nigella sativa and Lepidium sativum on cyclosporine pharmacokinetics," BioMed Research International, vol. 2013, Article ID 953520, 6 pages, 2013.

[116] U. K. Mazunder, M. Gupta, and Y. Rajeshwar, "Antihyperglycemic effect and antioxidant potential of Phyllanthus niruri (Euphorbiaceae) in streptozotocin induced diabetic rats," European Bulletin of Drug Research, vol. 13, no. 1, pp. 15-23, 2005.

[117] L. Taylor, Herbal Secret of Rainforest, Sagca Press, 2nd edition, 2003.

[118] G. Bagalkotkar, S. R. Sagineedu, M. S. Saad, and J. Stanslas, "Phytochemicals from Phyllanthus niruri Linn. and their pharmacological properties: a review," Journal of Pharmacy and Pharmacology, vol. 58, no. 12, pp. 1559-1570, 2006.

[119] R. Appiah-Opong, J. N. M. Commandeur, C. Axson, and N. P. E. Vermeulen, "Interactions between cytochromes P450, glutathione S-transferases and Ghanaian medicinal plants," Food and Chemical Toxicology, vol. 46, no. 12, pp. 3598-3603, 2008.

[120] T. Taesotikul, W. Dumrongsakulchai, N. Wattanachai et al., "Inhibitory effects of phyllanthus amarus and its major lignans on human microsomal cytochrome $\mathrm{P} 450$ activities: evidence for CYP3A4 mechanism-based inhibition," Drug Metabolism and Pharmacokinetics, vol. 26, no. 2, pp. 154-161, 2011.

[121] M. Wongnawa, P. Kaewmeesri, S. Sriwiriyajan, W. Mahatthanatrakul, and W. Ridtitid, "Effect of Phyllanthus amarus extract on the pharmacokinetics of midazolam in rabbits," Songklanakarin Journal of Science \& Technology, vol. 36, no. 5, pp. 547-553, 2014.

[122] T. Taesotikul, M. Nakajima, W. Tassaneeyakul, and T. Yokoi, "Effects of Phyllanthus amarus on the pharmacokinetics of midazolam and cytochrome $\mathrm{P} 450$ activities in rats," Xenobiotica, vol. 42, no. 7, pp. 641-648, 2012.

[123] M. Eddouks, M. Maghrani, A. Lemhadri, M.-L. Ouahidi, and H. Jouad, "Ethnopharmacological survey of medicinal plants used for the treatment of diabetes mellitus, hypertension and cardiac diseases in the south-east region of Morocco (Tafilalet)," Journal of Ethnopharmacology, vol. 82, no. 2-3, pp. 97-103, 2002.

[124] M. Zia-Ul-Haq, S. Ahmad, L. Calani et al., "Compositional study and antioxidant potential of Ipomoea hederacea Jacq. and Lepidium sativum L. seeds," Molecules, vol. 17, no. 9, pp. 1030610321, 2012.

[125] M. Eddouks and M. Maghrani, "Effect of Lepidium sativum L. on renal glucose reabsorption and urinary TGF- $\beta 1$ levels in diabetic rats," Phytotherapy Research, vol. 22, no. 1, pp. 1-5, 2008.

[126] F. I. Al-Jenoobi, A. A. Al-Thukair, M. A. Alam et al., "Effect of garden cress seeds powder and its alcoholic extract on the metabolic activity of CYP2D6 and CYP3A4," Evidence-Based Complementary and Alternative Medicine, vol. 2014, Article ID 634592, 6 pages, 2014.

[127] B. Higgins and B. Williams, "Pharmacological management of hypertension," Clinical Medicine, vol. 7, no. 6, pp. 612-616, 2007. 
[128] L. J. Beilin, "Non-pharmacological management of hypertension: optimal strategies for reducing cardiovascular risk," Journal of Hypertension, vol. 12, no. 10, pp. S71-S81, 1994.

[129] GRIN, Artemisia herba-alba Asso Taxonomy for Plants, Grin Global, 2010.

[130] R. Segal, I. Feuerstein, and A. Danin, "Chemotypes of Artemisia herba-alba in Israel based on their sesquiterpene lactone and essential oil constitution," Biochemical Systematics and Ecology, vol. 15, no. 4, pp. 411-416, 1987.

[131] A. Tahraoui, J. El-Hilaly, Z. H. Israili, and B. Lyoussi, "Ethnopharmacological survey of plants used in the traditional treatment of hypertension and diabetes in south-eastern Morocco (Errachidia province)," Journal of Ethnopharmacology, vol. 110, no. 1, pp. 105-117, 2007.

[132] N.-A. Zeggwagh, O. Farid, J. B. Michel, and M. Eddouks, "Cardiovascular effect of Artemisia herba alba aqueous extract in spontaneously hypertensive rats," Methods and Findings in Experimental and Clinical Pharmacology, vol. 30, no. 5, pp. 375381, 2008.

[133] A. E.-H. H. Mohamed, M. A. El-Sayed, M. E. Hegazy, S. E. Helaly, A. M. Esmail, and N. S. Mohamed, "Chemical constituents and biological activities of Artemisia herba-alba," Records of Natural Products, vol. 4, no. 1, pp. 1-25, 2010.

[134] A.-H. Mohamed, A. M. Esmail, and A. M. El-Saade, “Terpenes from Artemisia herba-alba," Zeitschrift für Naturforschung C, vol. 68, no. 9-10, pp. 343-346, 2013.

[135] M. Laid, M.-E. F. Hegazy, A. A. Ahmed, K. Ali, D. Belkacemi, and S. Ohta, "Sesquiterpene lactones from Algerian Artemisia herba-alba," Phytochemistry Letters, vol. 1, no. 2, pp. 85-88, 2008.

[136] A. Moufid and M. Eddouks, "Artemisia herba alba: a popular plant with potential medicinal properties," Pakistan Journal of Biological Sciences, vol. 15, no. 24, pp. 1152-1159, 2012.

[137] S. Zouari, N. Zouari, N. Fakhfakh, A. Bougatef, M. A. Ayadi, and M. Neffati, "Chemical composition and biological activities of a new essential oil chemotype of Tunisian Artemisia herba alba Asso," Journal of Medicinal Plants Research, vol. 4, no. 10, pp. 871-880, 2010.

[138] C. Ulbricht, W. Chao, D. Costa, E. Rusie-Seamon, W. Weissner, and J. Woods, "Clinical evidence of herb-drug interactions: a systematic review by the natural standard research collaboration," Current Drug Metabolism, vol. 9, no. 10, pp. 1063-1120, 2008.

[139] D. Khlifi, R. M. Sghaier, S. Amouri, D. Laouini, M. Hamdi, and J. Bouajila, "Composition and anti-oxidant, anti-cancer and antiinflammatory activities of Artemisia herba-alba, Ruta chalpensis L. and Peganum harmala L.," Food and Chemical Toxicology, vol. 55, pp. 202-208, 2013.

[140] O. Pelkonen, K. Abass, and J. Wiesner, "Thujone and thujonecontaining herbal medicinal and botanical products: toxicological assessment," Regulatory Toxicology and Pharmacology, vol. 65, no. 1, pp. 100-107, 2013.

[141] H. A. Wahabi, L. A. Alansary, A. H. Al-Sabban, and P. Glasziuo, "The effectiveness of Hibiscus sabdariffa in the treatment of hypertension: a systematic review," Phytomedicine, vol. 17, no. 2, pp. 83-86, 2010.

[142] M. H. Faraji and A. H. H. Tarkhani, "The effect of sour tea (Hibiscus sabdariffa) on essential hypertension," Journal of Ethnopharmacology, vol. 65, no. 3, pp. 231-236, 1999.

[143] A. Herrera-Arellano, S. Flores-Romero, M. A. Chávez-Soto, and J. Tortoriello, "Effectiveness and tolerability of a standardized extract from Hibiscus sabdariffa in patients with mild to moderate hypertension: a controlled and randomized clinical trial," Phytomedicine, vol. 11, no. 5, pp. 375-382, 2004.

[144] O. O. Ndu, C. S. Nworu, C. O. Ehiemere, N. C. Ndukwe, and I. S. Ochiogu, "Herb-drug interaction between the extract of Hibiscus sabdariffa L. and hydrochlorothiazide in experimental animals," Journal of Medicinal Food, vol. 14, no. 6, pp. 640-644, 2011.

[145] S. S. Johnson, F. T. Oyelola, T. Ari, and H. Juho, "In vitro inhibitory activities of the extract of Hibiscus sabdariffa L. (family Malvaceae) on selected cytochrome P450 isoforms," African journal of traditional, complementary, and alternative medicines, vol. 10, no. 3, pp. 533-540, 2013.

[146] P. Prommetta, L. Phivthong-Ngam, C. Chaichantipyuth, N. Niwattisaiwong, and S. Lawanprasert, "Aqueous extract of the calyces of Hibiscus subdariffa Linn.: effects on hepatic cytochrome P450 and subacute toxicity in rats," Thai Journal of Pharmaceutical Sciences, vol. 30, pp. 8-18, 2006.

[147] H. M. Abdallah, A. M. Al-Abd, R. S. El-Dine, and A. M. ElHalawany, "P-glycoprotein inhibitors of natural origin as potential tumor chemo-sensitizers: a review," Journal of Advanced Research, vol. 6, no. 1, pp. 45-62, 2015.

[148] M. M. Gottesman, T. Fojo, and S. E. Bates, "Multidrug resistance in cancer: role of ATP-dependent transporters," Nature Reviews Cancer, vol. 2, no. 1, pp. 48-58, 2002.

[149] G. Bradley and V. Ling, "P-glycoprotein, multidrug resistance and tumor progression," Cancer and Metastasis Reviews, vol. 13, no. 2, pp. 223-233, 1994.

[150] H. Thomas and H. M. Coley, "Overcoming multidrug resistance in cancer: an update on the clinical strategy of inhibiting pglycoprotein," Cancer Control, vol. 10, no. 2, pp. 159-165, 2003.

[151] R. J. Kelly, D. Draper, C. C. Chen et al., "A pharmacodynamic study of docetaxel in combination with the P-glycoprotein antagonist tariquidar (XR9576) in patients with lung, ovarian, and cervical cancer," Clinical Cancer Research, vol. 17, no. 3, pp. 569-580, 2011.

[152] R. J. Kelly, R. W. Robey, C. C. Chen et al., "A pharmacodynamic study of the P-glycoprotein antagonist CBT- $1^{\circledR}$ in combination with paclitaxel in solid tumors," The Oncologist, vol. 17, no. 4, p. 512, 2012.

[153] G. M. Cragg and D. J. Newman, "Plants as a source of anticancer agents," Journal of Ethnopharmacology, vol. 100, no. 1-2, pp. 72-79, 2005.

[154] J.-E. Kim, H.-J. Cho, J. S. Kim et al., "The limited intestinal absorption via paracellular pathway is responsible for the low oral bioavailability of doxorubicin," Xenobiotica, vol. 43, no. 7 , pp. 579-591, 2013.

[155] M. A. Bisi-Johnson, C. L. Obi, T. Hattori et al., "Evaluation of the antibacterial and anticancer activities of some South African medicinal plants," BMC Complementary and Alternative Medicine, vol. 11, no. 1, article 14, 2011.

[156] M. E. M. Saeed, M. Meyer, A. Hussein, and T. Efferth, "Cytotoxicity of South-African medicinal plants towards sensitive and multidrug-resistant cancer cells," Journal of Ethnopharmacology, vol. 186, pp. 209-223, 2016.

[157] V. Steenkamp and M. C. Gouws, "Cytotoxicity of six South African medicinal plant extracts used in the treatment of cancer," South African Journal of Botany, vol. 72, no. 4, pp. 630633, 2006.

[158] W. S. El-Deiry, "Role of oncogenes in resistance and killing by cancer therapeutic agents," Current Opinion in Oncology, vol. 9, no. 1, pp. 79-87, 1997. 
[159] Y. Shetzer, H. Solomon, G. Koifman, A. Molchadsky, S. Horesh, and V. Rotter, "The paradigm of mutant p53-expressing cancer stem cells and drug resistance," Carcinogenesis, vol. 35, no. 6, pp. 1196-1208, 2014.

[160] M. C. Da Silva, S. Izidine, and A. B. Amude, A Preliminary Checklist of the Vascular Plants of Mozambique, Sabonet, 2004.

[161] B.-E. Van Wyk, F. van Heerden, and B. van Oudtshoorn, Poisonous Plants of South Africa, Briza Publications, Pretoria, South Africa, 2002.

[162] G. Fouche, G. M. Cragg, P. Pillay, N. Kolesnikova, V. J. Maharaj, and J. Senabe, "In vitro anticancer screening of South African plants," Journal of Ethnopharmacology, vol. 119, no. 3, pp. 455$461,2008$.

[163] C. Riganti, I. Campia, J. Kopecka et al., "Pleiotropic effects of cardioactive glycosides," Current Medicinal Chemistry, vol. 18, no. 6, pp. 872-885, 2011.

[164] M. Zeino, M. S. Paulsen, M. Zehl, E. Urban, B. Kopp, and T. Efferth, "Identification of new P-glycoprotein inhibitors derived from cardiotonic steroids," Biochemical Pharmacology, vol. 93, no. 1, pp. 11-24, 2015.

[165] F. Brouillard, D. Tondelier, A. Edelman, and M. BaudouinLegros, "Drug resistance induced by ouabain via the stimulation of MDR1 gene expression in human carcinomatous pulmonary cells," Cancer Research, vol. 61, no. 4, pp. 1693-1698, 2001.

[166] M. S. Abubakar, A. M. Musa, A. Ahmed, and I. M. Hussaini, "The perception and practice of traditional medicine in the treatment of cancers and inflammations by the Hausa and Fulani tribes of Northern Nigeria," Journal of Ethnopharmacology, vol. 111, no. 3, pp. 625-629, 2007.

[167] E. Ajaiyeoba, M. Falade, O. Ogbole, L. Okpako, and D. Akinboye, Short Communication-In Vivo Antimalarial and Cytotoxic Properties of Annona Senegalensis Extract, African Ethnomedicines Network, 2006.

[168] M. You, D. B. M. Wickramaratne, G. L. Silva et al., “(-)Roemerine, an aporphine alkaloid from Annona senegalensis that reverses the multidrug-resistance phenotype with cultured cells," Journal of Natural Products, vol. 58, no. 4, pp. 598-604, 1995.

[169] N. Duarte, A. Járdánházy, J. Molnár, A. Hilgeroth, and M.-J. U. Ferreira, "Synergistic interaction between p-glycoprotein modulators and epirubicine on resistant cancer cells," Bioorganic \& Medicinal Chemistry, vol. 16, no. 20, pp. 9323-9330, 2008.

[170] A. A. Adeneye, O. Awodele, S. A. Aiyeola, and A. S. Benebo, "Modulatory potentials of the aqueous stem bark extract of Mangifera indica on carbon tetrachloride-induced hepatotoxicity in rats," Journal of Traditional and Complementary Medicine, vol. 5, no. 2, pp. 106-115, 2015.

[171] J. Ojewole, "Antiinflammatory, analgesic and hypoglycemic effects of Mangifera indica Linn. (Anacardiaceae) stem-bark aqueous extract," Methods and Findings in Experimental and Clinical Pharmacology, vol. 27, no. 8, pp. 547-554, 2005.

[172] K. Shah, M. Patel, R. Patel, and P. Parmar, "Mangifera indica (mango)," Pharmacognosy Reviews, vol. 4, no. 7, pp. 42-48, 2010.

[173] M. Louisa, T. M. Soediro, and F. D. Suyatna, "In vitro modulation of P-glycoprotein, MRP-1 and BCRP expression by mangiferin in doxorubicin-treated MCF-7 cells," Asian Pacific Journal of Cancer Prevention, vol. 15, no. 4, pp. 1639-1642, 2014.

[174] I. Rodeiro, M. José Gómez-Lechón, G. Perez et al., "Mangifera indica L. extract and mangiferin modulate cytochrome P450 and UDP-glucuronosyltransferase enzymes in primary cultures of human hepatocytes," Phytotherapy Research, vol. 27, no. 5, pp. 745-752, 2013.
[175] N. Duarte, H. Lage, M. Abrantes, and M.-J. U. Ferreira, "Phenolic compounds as selective antineoplasic agents against multidrug-resistant human cancer cells," Planta Medica, vol. 76, no. 10, pp. 975-980, 2010.

[176] T. A. Mansoor, R. M. Ramalho, C. M. P. Rodrigues, and M.-J. U. Ferreira, "Dibenzylbutane- and butyrolactone-type lignans as apoptosis inducers in human hepatoma HuH-7 cells," Phytotherapy Research, vol. 26, no. 5, pp. 692-696, 2012.

[177] B.-E. Van Wyk and C. Albrecht, "A review of the taxonomy, ethnobotany, chemistry and pharmacology of Sutherlandia frutescens (Fabaceae)," Journal of Ethnopharmacology, vol. 119, no. 3, pp. 620-629, 2008.

[178] X. Fu, X.-C. Li, T. J. Smillie et al., "Cycloartane glycosides from Sutherlandia frutescens," Journal of Natural Products, vol. 71, no. 10, pp. 1749-1753, 2008.

[179] X. Fu, X.-C. Li, Y.-H. Wang et al., "Flavonol glycosides from the South African medicinal plant Sutherlandia frutescens," Planta Medica, vol. 76, no. 2, pp. 178-181, 2010.

[180] J. Tai, S. Cheung, E. Chan, and D. Hasman, "In vitro culture studies of Sutherlandia frutescens on human tumor cell lines," Journal of Ethnopharmacology, vol. 93, no. 1, pp. 9-19, 2004.

[181] C. Vorster, A. Stander, and A. Joubert, "Differential signaling involved in Sutherlandia frutescens-induced cell death in MCF7 and MCF-12A cells," Journal of Ethnopharmacology, vol. 140, no. 1, pp. 123-130, 2012.

[182] T. V. Mqoco, M. H. Visagie, C. Albrecht, and A. M. Joubert, "Differential cellular interaction of Sutherlandia frutescens extracts on tumorigenic and non-tumorigenic breast cells," South African Journal of Botany, vol. 90, pp. 59-67, 2014.

[183] Y. Lu, N. Starkey, W. Lei et al., "Inhibition of hedgehog-signaling driven genes in prostate cancer cells by Sutherlandia frutescens extract," PLoS ONE, vol. 10, no. 12, Article ID e0145507, 2015.

[184] G. Leisching, B. Loos, T. Nell, and A.-M. Engelbrecht, "Sutherlandia frutescens treatment induces apoptosis and modulates the PI3-kinase pathway in colon cancer cells," South African Journal of Botany, vol. 100, pp. 20-26, 2015.

[185] P. S. Fasinu, H. Gutmann, H. Schiller, A.-D. James, P. J. Bouic, and B. Rosenkranz, "The potential of sutherlandia frutescens for herb-drug interaction," Drug Metabolism and Disposition, vol. 41, no. 2, pp. 488-497, 2013.

[186] P. Limtrakul, O. Khantamat, and K. Pintha, "Inhibition of P-glycoprotein function and expression by kaempferol and quercetin," Journal of Chemotherapy, vol. 17, no. 1, pp. 86-95, 2005.

[187] A. C. Müller, M. F. Skinner, and I. Kanfer, "Effect of the African traditional medicine, Sutherlandia frutescens, on the bioavailability of the antiretroviral protease inhibitor, atazanavir," Evidence-based Complementary and Alternative Medicine, vol. 2013, Article ID 324618, 6 pages, 2013.

[188] M. Minocha, N. K. Mandava, D. Kwatra et al., "Effect of short term and chronic administration of Sutherlandia frutescens on pharmacokinetics of nevirapine in rats," International Journal of Pharmaceutics, vol. 413, no. 1-2, pp. 44-50, 2011.

[189] M. Moudi, R. Go, C. Y. S. Yien, and M. Nazre, "Vinca alkaloids," International Journal of Preventive Medicine, vol. 4, no. 11, pp. 1231-1235, 2013.

[190] H. Quan, Y. Xu, L. Hu, and L. Lou, "Abstract 2053: F-XA7, a novel derivative of vinca alkaloid with potent antitumor activity, efficiently overrides P-glycoprotein-mediated drug resistance both in vitro and in vivo," Cancer Research, vol. 73 , no. 8 , supplement, p. 2053, 2013. 
[191] R. Mittra, E. M. Coyle, and R. Callaghan, "Just how and where does P-glycoprotein bind all those drugs?" in $A B C$ Transporters-40 Years on, pp. 153-194, Springer, Berlin, Germany, 2016.

[192] P. Limtrakul, O. Khantamat, and K. Pintha, "Inhibition of Pglycoprotein activity and reversal of cancer multidrug resistance by Momordica charantia extract," Cancer Chemotherapy and Pharmacology, vol. 54, no. 6, pp. 525-530, 2004.

[193] Q. Mi, B. Cui, G. L. Silva et al., "Pervilleine A, a novel tropane alkaloid that reverses the multidrug-resistance phenotype," Cancer Research, vol. 61, no. 10, pp. 4030-4037, 2001.

[194] N. F. Smith, S. Mani, E. G. Schuetz et al., "Induction of CYP3A4 by vinblastine: role of the nuclear receptor NR1I2," Annals of Pharmacotherapy, vol. 44, no. 11, pp. 1709-1717, 2010.

[195] S. E. Drewes, E. Elliot, F. Khan, J. T. B. Dhlamini, and M. S. S. Gcumisa, "Hypoxis hemerocallidea-not merely a cure for benign prostate hyperplasia," Journal of Ethnopharmacology, vol. 119, no. 3, pp. 593-598, 2008.

[196] J. Watt and M. Breyer Brandwijk, Medicinal and Poisonous Plants of Southern and Eastern Africa, E. \& S. Livingstone Ltd, Edinburgh, UK, 2nd edition, S. \& E. Africa.[At Museum.] Review article General article, Drug plants Medicinal plants Pharmacognosy Materia medica, Toxic plants Poisonous plants, geog, 1962.

[197] C. Albrecht, "Hypoxoside: a putative prodrug for the treatment of malignancies, HIV infections, and inflammatory conditions," South African Medical Journal, vol. 85, pp. 302-307, 1995.

[198] A. Hutchings, A. H. Scott, G. Lewis, and A. Cunningham, Zulu Medicinal Plants: An Inventory, University of Kwazulu Natal Press, 1996.

[199] B.-E. Van Wyk and N. Gericke, People's Plants: A Guide to Useful Plants of Southern Africa, Briza Publications, Pretoria, South Africa, 2000.

[200] M. J. Van Der Merwe, K. Jenkins, E. Theron, and B. J. Van Der Walt, "Interaction of the di-catechols rooperol and nordihydroguaiaretic acid with oxidative systems in the human blood: a structure-activity relationship," Biochemical Pharmacology, vol. 45, no. 2, pp. 303-311, 1993.

[201] C. F. Albrecht, E. J. Theron, and P. B. Kruger, "Morphological characterisation of the cell-growth inhibitory activity of rooperol and pharmacokinetic aspects of hypoxoside as an oral prodrug for cancer therapy," South African Medical Journal, vol. 85, no. 9, pp. 853-860, 1995.

[202] G. J. Boukes, The in vitro biological activities of three Hypoxis species and their active compounds [Ph.D. thesis], 2010.

[203] P. S. Fasinu, H. Gutmann, H. Schiller, P. J. Bouic, and B. Rosenkranz, "The potential of Hypoxis hemerocallidea for herbdrug interaction," Pharmaceutical Biology, vol. 51, no. 12, pp. 1499-1507, 2013.

[204] Y. Naritomi, S. Terashita, and A. Kagayama, "Identification and relative contributions of human cytochrome P450 isoforms involved in the metabolism of glibenclamide and lansoprazole: evaluation of an approach based on the in vitro substrate disappearance rate," Xenobiotica, vol. 34, no. 5, pp. 415-427, 2004.

[205] A. J. Scheen, "Pharmacokinetic interactions with thiazolidinediones," Clinical Pharmacokinetics, vol. 46, no. 1, pp. 1-12, 2007.

[206] D. A. Flockhart and J. E. Tanus-Santos, "Implications of cytochrome $\mathrm{P} 450$ interactions when prescribing medication for hypertension," Archives of Internal Medicine, vol. 162, no. 4, pp. 405-412, 2002.
[207] T. Takanohashi, S. Kubo, A. Nakayama, R. Mihara, and M. Hayashi, "Inhibition of human liver microsomal CYP by nateglinide," Journal of Pharmacy and Pharmacology, vol. 62, no. 5, pp. 592-597, 2010.

[208] S.-M. He, A.-K. Yang, X.-T. Li, Y.-M. Du, and S.-F. Zhou, "Effects of herbal products on the metabolism and transport of anticancer agents," Expert Opinion on Drug Metabolism \& Toxicology, vol. 6, no. 10, pp. 1195-1213, 2010.

[209] S. J. Baldwin, S. E. Clarke, and R. J. Chenery, "Characterization of the cytochrome P450 enzymes involved in the in vitro metabolism of rosiglitazone," British Journal of Clinical Pharmacology, vol. 48, no. 3, pp. 424-432, 1999.

[210] D. F. V. Lewis, "Human cytochromes P450 associated with the phase 1 metabolism of drugs and other xenobiotics: a compilation of substrates and inhibitors of the CYP1, CYP2 and CYP3 families," Current Medicinal Chemistry, vol. 10, no. 19, pp. 1955-1972, 2003.

[211] T. Lynch and A. Price, "The effect of cytochrome P450 metabolism on drug response, interactions, and adverse effects," American Family Physician, vol. 76, no. 3, pp. 391-396, 2007.

[212] A. Scomparin, S. Salmaso, A. Eldar-Boock et al., "A comparative study of folate receptor-targeted doxorubicin delivery systems: dosing regimens and therapeutic index," Journal of Controlled Release, vol. 208, pp. 106-120, 2015.

[213] S. Sharad, M. Patel, M. Bhuch, M. Chatterjee, and S. Shrivastava, "Regulatory status of traditional medicines in Africa Region," International Journal of Research in Ayurveda and Pharmacy, vol. 2, no. 1, pp. 103-110, 2011. 


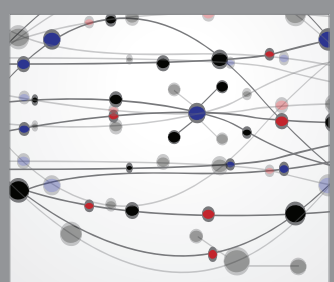

The Scientific World Journal
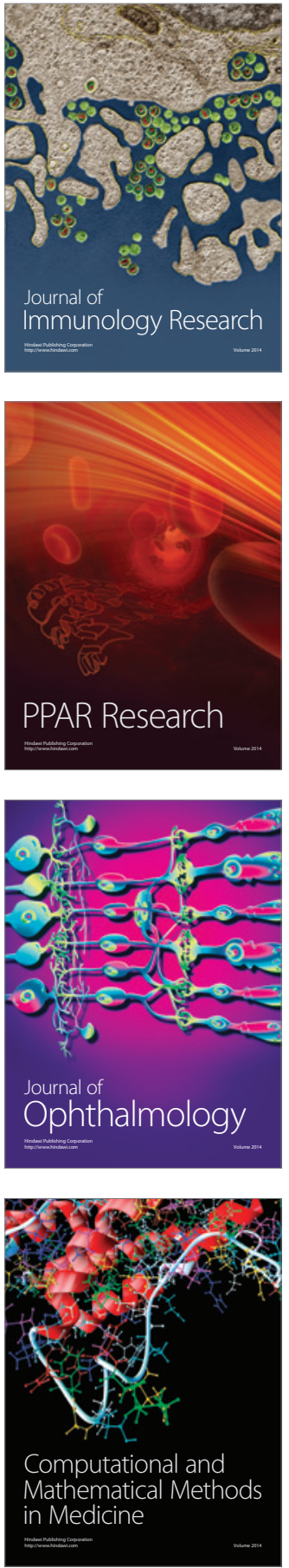

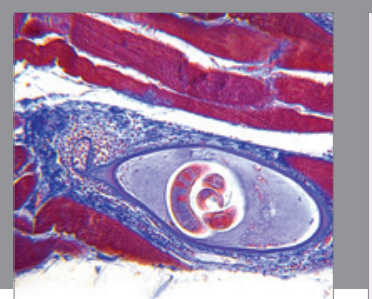

Gastroenterology Research and Practice
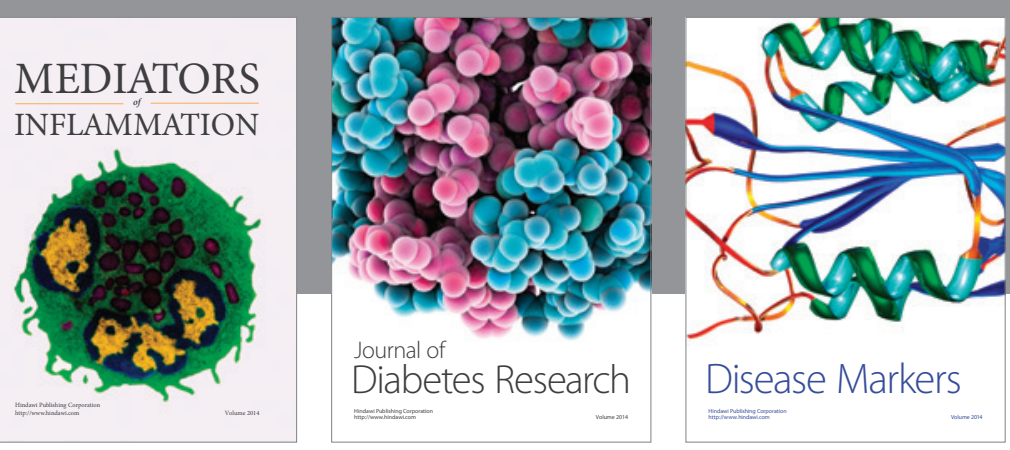

Disease Markers

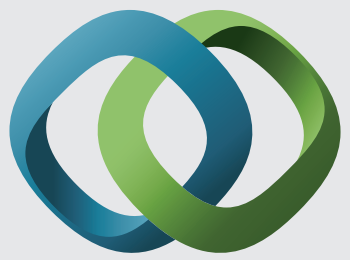

\section{Hindawi}

Submit your manuscripts at

https://www.hindawi.com
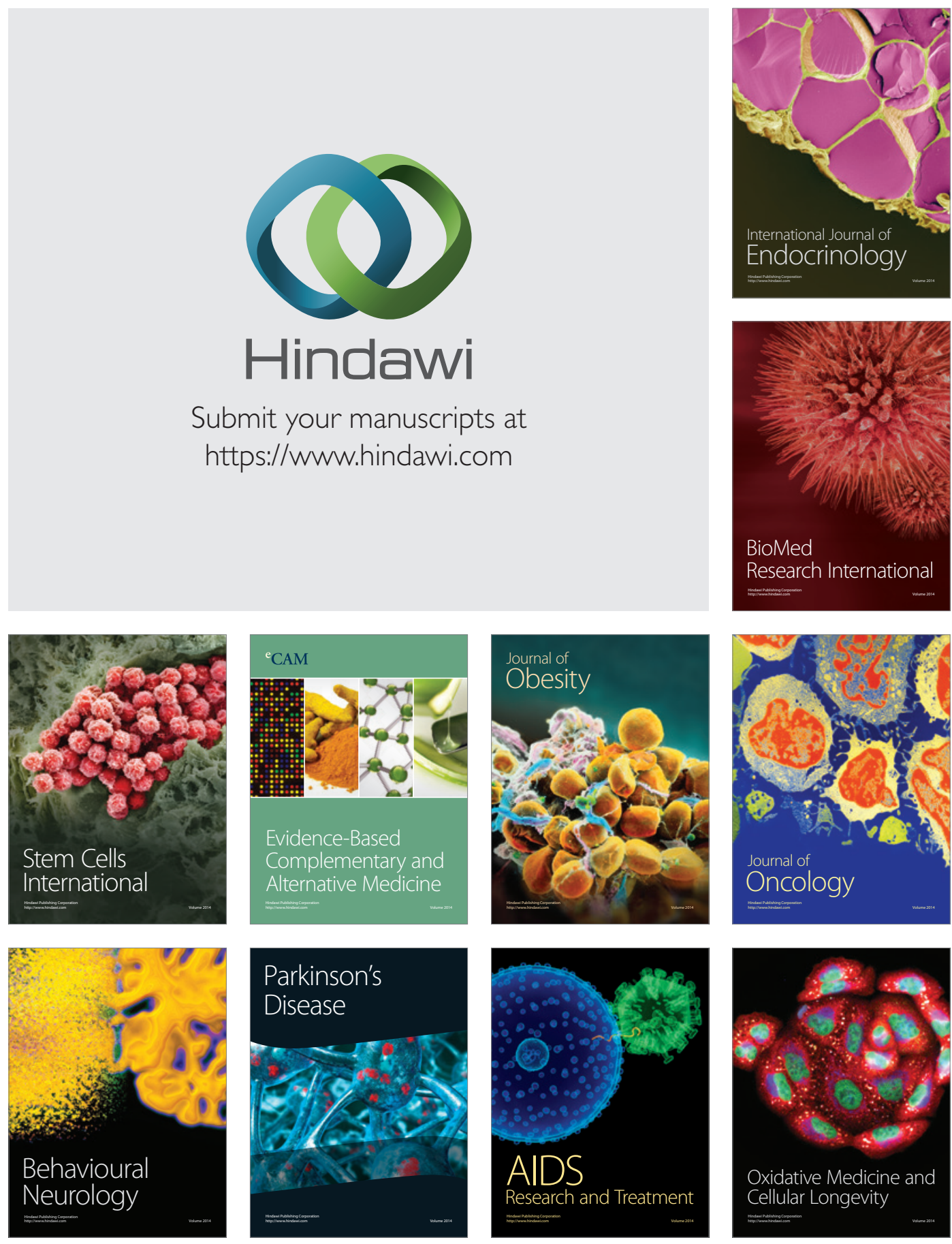